\title{
СУЛЬФАТНЫЕ МИНЕРАЛЬНЫЕ ОЗЕРА ЗАПАДНОГО ЗАБАЙКАЛЬЯ: УСЛОВИЯ ОБРАЗОВАНИЯ, ХИМИЧЕСКИЙ СОСТАВ ВОДЫ И ДОННЫХ ОТЛОЖЕНИЙ
}

Плюснин А. М., Хажеева 3. И., Санжанова С. С., Перязева Е. Г., Ангахаева Н. А.

\begin{abstract}
Аннотация
В статье рассмотрены закономерности формирования химического состава вод в сульфатных минеральных озерах Западного Забайкалья. Показано, что сульфатный натриевый тип вод в озерах региона формируется в двух очагах континентального засоления - в Баргузинской и Гусиноозерско-Оронгойской впадинах. Общая минерализация в озерах достигает 30,8 г/л, $\mathrm{pH}=7,9-$ 8,84, доля сульфат-иона от 55,2 до 81,8 мг-экв.\%, доля натрия от 59,1 до 82,1 мг-экв.\%. В работе приведен макро-микроэлементный, состав вод озер. Представлены результаты исследования химического и минералогического состава донных отложений. Показано, что определяющую роль в образовании озер играет их питание подземными водами, обогащенными сульфатом натрия.
\end{abstract}

\section{Ключевые слова:}

минеральные озера, испарение, вымораживание, сульфат-ион, микроэлементы, редкоземельные элементы, изотопный состав, донные отложения. 
УДК 556.332.62

\title{
СУЛЬФАТНЫЕ МИНЕРАЛЬНЫЕ ОЗЕРА ЗАПАДНОГО ЗАБАЙКАЛЬЯ: УСЛОВИЯ ОБРАЗОВАНИЯ, ХИМИЧЕСКИЙ СОСТАВ ВОДЫ И ДОННЫХ ОТЛОЖЕНИЙ
}

\author{
А.М.Плюснин ${ }^{1,2}$, 3.И.Хажеева ${ }^{1}$, С.С.Санжанова ${ }^{1}$, Е.Г. Перязева ${ }^{1}$, Н.А. Ангахаева ${ }^{1}$ \\ ${ }^{1}$ Геологический институт СО РАН, 670047, Улан-Удэ, ул. Сахьяновой $6 а$ \\ ${ }^{2}$ Восточно-Сибирскийгосударственный университет технологий и управления, \\ 670013, г.Улан-Удэ, ул. Ключевская, д.40В, строение 1 \\ E-mail:plyusnin@ginst.ru
}

\begin{abstract}
Аннотация. В статье рассмотрены закономерности формирования химического состава вод в сульфатных минеральных озерах Западного Забайкалья. Показано, что сульфатный натриевый тип вод в озерах региона формируется в двух очагах континентального засоления - в Баргузинской и Гусиноозерско-Оронгойской впадинах. Общая минерализация в озерах достигает 30,8 г/л, $\mathrm{pH}=7,9-8,84$, доля сульфат-иона от 55,2 до 81,8 мг-экв.\%, доля натрия от 59,1 до 82,1 мг-экв.\%. В работе приведен макромикроэлементный, состав вод озер. Представлены результаты исследования химического и минералогического состава донных отложений. Показано, что определяющую роль в образовании озер играет их питание подземными водами, обогащенными сульфатом натрия.
\end{abstract}

Ключевые слова: минеральные озера, испарение, вымораживание, сульфат-ион, микроэлементы, редкоземельные элементы, изотопный состав, донные отложения.

\section{SULFATE MINERAL LAKES OF WESTERN TRANSBAIKALIA: FORMATION CONDITIONS, WATER CHEMICAL COMPOSITION AND BOTTOM SEDIMENTS}

\author{
A.M. Plyusnin, Z.I. Khazheeva, S.S. Sanzhanova, E.G. Peryazeva, N.A. Angakhaeva \\ Geological Institute SB RAS, 670047, Ulan-Ude, Sakh’yanovoy St, 6a
}

\begin{abstract}
Formation patterns of the chemical composition of water in the sulfate mineral lakes of Western Transbaikalia are discussed in the paper. It is demonstrated that sodium sulfate water type in the region's lakes forms in two zones of continental salting - the Barguzin and Gusinoozersk-Orongoy depressions. The average mineralization of lakes is up to $30.8 \mathrm{~g} / \mathrm{l}$, $\mathrm{pH}=7.9-8.84$, fractional content of sulfate ion is 55.2-81.8 and sodium is $59.1-82.1 \mathrm{mg}$ eq.\%. The chemical and isotopic composition of substances dissolved in water is presented in the paper. The results of the study of the chemical and mineralogical composition of bottom sediments are submitted. It is shown that groundwater enriched by sodium sulfate plays a major role in the formation of lakes.
\end{abstract}

Keywords: mineral lakes, evaporation, freezing out, sulfate ion, trace elements, rare earth elements, isotopic composition, bottom sediments.

\section{ВВЕДЕНИЕ}

Условия образования разных по химическому составу и минерализации озер являются предметом исследований во многих регионах мира. Многочисленные научные 
публикации посвящены гидрохимии озер США [Baker et. al., 1991], Канады [Last, Fawn, 2005], Европы [Stojanovic, Kogelniga, 2009], Средней Азии [Volkova, 1998] и других регионов мира. В России аналогичные исследования проводятся в Европейской части страны [Моисеенко, Ганшина, 2010], Западной Сибири [Леонова и др., 2007; Таран и др., 2018], Прибайкалье и Забайкалье [Борзенко и др., 2014; Скляров и др., 2011; Склярова и др., 2002, 2011; Страховенко, Гаськова , 2018; Страховенко и др., 2018]. Интересные результаты получены по Великим равнинам Канады, где исследовано около 500 озер с различной минерализацией и химическим составом воды [Last, Fawn, 2005]. В результате статистической обработки анализов выявлено, что главными факторами, контролирующими химический состав озерных вод в этом районе, являются состав питающих подземных вод, соотношение увлажнения и испарения, а также высотное положение озер в пределах водосборной площади. Для озер европейской части России на основании обработки большого массива данных было установлено, что основными факторами формирования химического состава озерных вод являются: географическая зональность, региональные особенности в виде близости моря, гумификация, засоление и антропогенная нагрузка [Моисеенко, Ганшина, 2010].

Формирование химического состава минеральных озер большинством исследователей связывается с испарительным концентрированием. Определяющее влияние на особенности химического состава вод оказывает влияние горные породы, с которыми взаимодействует вода [Основы гидрогеологии, 1982; Домрочева, Лепокурова, 2015]. Устанавливается «равновесно-неравновесное» динамическое взаимодействие между водой и вмещающими ее породами, в этой системе достигается равновесие с образующимися вторичными минералами и никогда не достигается с первичными алюмосиликатами [Шварцев, 1991, 1998, 2006]. В результате протекания процессов растворения-осаждения в растворе накапливаются натрий и гидрокарбонат-ион. Затем, по мере накопления растворенных веществ химический состав трансформируется до гидрокарбонатно-хлоридных и хлоридных натриевых вод. Ранее предполагалось, что трансформация химического состава вод до хлоридного типа проходит через образование сульфатного типа вод. Считалось, что сульфатные воды образуются при прямой метаморфизации химического состава вод с ростом их общей минерализации и этому посвящена обширная литература [Посохов, 1969; Blake, 1989; Kimura, 1992; Parkhurst et. al., 1996]. Но полученные в последние годы данные не подтверждают это. Образование очагов сульфатного засоления стоит особняком, в стороне от общего направления трансформации химического состава минеральных озер. Для формирования вод сульфатного типа необходимы дополнительные источники серы. Поступление серы в озера может быть связано с выветриванием пород с аномально высоким содержанием сульфидной минерализации, растворением сульфатсодержащих пород, разгрузкой трещинно-жильных и пластовых вод глубоких водоносных горизонтов.

Представленная работа направлена на выявление основных факторов, которые определяют формирование сульфатного химического типа озер Западного Забайкалья и установлению их геохимических особенностей.

\section{МЕТОДЫ ИССЛЕДОВАНИЯ}

Пробы воды и донных отложений из озер отбирали не менее 1,5-2 м от берега с глубины 0,5-1 м. На месте отбора всех проб определяли температуру, электропроводность, $\mathrm{pH}$, Eh, растворённый кислород. Воду для анализа макрокомпонентов отбирали в 
пластиковые 1,5 - литровые бутылки. Пробы воды на микроэлементы набирали в полиэтиленовые контейнеры (15 мл), предварительно подготовленные в лаборатории обработкой $\mathrm{HNO}_{3} 0,1 \mathrm{~N}$ и промытые деионизированной водой. На месте отбора проб образцы воды были пропущены через фильтры с размерами пор 0,45 мкм и подкислены дважды очищенной 0,1N азотной кислотой до $\mathrm{pH}=1-2$.

Анализ макрокомпонентного состава воды выполнен в сертифицированной лаборатории Геологического института СО РАН (г. Улан-Удэ) по стандартным методикам для пресных и соленых вод. Катионы $\left(\mathrm{Ca}^{2+}, \mathrm{Mg}^{2+}, \mathrm{Na}^{+}, \mathrm{K}^{+}\right)$определяли методами атомной абсорбции, $\mathrm{F}^{-}, \mathrm{SiO}_{2}-$ колориметрическим, $\mathrm{HCO}_{3}{ }^{-}, \mathrm{CO}_{3}{ }^{2-}$ и $\mathrm{Cl}^{-}-$титриметрическим, $\mathrm{SO}_{4}{ }^{2-}-$ турбидиметрическим методами.

Определение микроэлементного состава воды выполнено методом ICP-MS на массспектрометре с двойной фокусировкой, магнитным сектором и поперечно-потоковым распылителем ELEMENT XR (Thermo Finnigan, Bremen, Германия) в центре коллективного пользования Геологического института СО PAH (Улан-Удэ). Калибровочные растворы приготовлены разбавлением многоэлементных стандартных растворов CLMS-1,2,3 (SPEX, США). При приготовлении всех растворов использована деионизированная вода, очищенная системой Elix-3/Milli-Q (Франция). Правильность анализа контролировалась с помощью сертифицированного раствора IQC (NIST, США).

Пробы донных отложений отбирались пробоотборником Паттерсона из слоя осадков 0-20 см в различных местоположениях, охватывающих разнообразие субаквальных ландшафтов озер, с глубины от 0,4 до 3,5 м. Всего было взято 32 пробы. Непосредственно после отбора проб в полевой лаборатории были измерены $\mathrm{pH}$ осадка, влажность. В лаборатории отобранные пробы были просушены при $105^{\circ} \mathrm{C}$, озолены в муфельной печи для определения содержания органических веществ. Валовый макро- и микроэлементный состав образцов донных отложений определен рентгенофлуоресцентным методом на спектрометре ARL Perform X-4200 (Швейцария). Минеральный состав донных осадков определяли методом рентгеноструктурного анализа на дифрактометре DS Advance фирмы Bruker (Германия) CuK-излучение, детектор Vantec1, обработка данных по программе EVA, база данных ICDD (2003 г.).

\section{ОБЩИЕ ЗАКОНОМЕРНОСТИ ОБРАЗОВАНИЯ МИНЕРАЛЬНЫХ ОЗЕР В ЗАПАДНОМ ЗАБАЙКАЛЬЕ}

В рассматриваемом регионе широко распространены озера с минерализацией более 1 г/л, их называют минеральными или солеными озерами. Все они приурочены к лесостепной и степной ландшафтно-климатическим зонам. Водно-солевое питание озера получают за счет атмосферных осадков, выветривания и последующего выщелачивания окружающих их горных пород, а также за счет разгрузки подземных вод.

Концентрирование растворенного вещества в озерах связано с удалением растворителя, что происходит в условиях Забайкалья в результате протекания процессов испарения и вымораживания [Дзюба и др., 1999]. Испарительное концентрирование связано с тем, что здесь летом господствуют аридные условия. Испарение влаги с водной поверхности в среднем составляет 1000 мм/год [Иванов, Трофимов, 1982]. В засушливый период это приводит к значительному снижению уровня воды в озерах и концентрированию солей. Многие озера, особенно небольшие по размерам, в засушливые годы полностью пересыхают [Замана, Борзенко, 2010]. 
При пересыхании озер соли из котловин выносятся ветром, при этом потери сульфата натрия как более легкой соли больше, нежели потери хлористого натрия. Низкая температура воздуха в зимнее время и небольшой снежный покров приводят к промораживанию мелких озер до самого дна. При замерзании озера, по мере образования льда повышается концентрация солей в растворе и соответственно понижается его температура замерзания. Первой твердой фазой, выделяющейся из вод при вымораживании, является карбонат кальция. Выделение карбоната кальция начинается при температуре около нуля градусов. При дальнейшем понижении температуры последовательность выделения солей в твердую фазу определяется их эвтектическими температурами и составом растворов. Хлористые соли натрия и магния обычно начинают удаляться из растворов последними. При полном промерзании соленого озера на дне высаживаются все соли, находящиеся в растворе. При таянии ледяного покрова и поступлении воды из других источников, образовавшаяся новосадка кальцита, мирабилита, соды, галита иногда не успевает раствориться в течение года, в этом случае на дне озера накапливается слой соли, который называется старосадкой. Эти соли перемешиваются с илом, перекрываются терригенными осадками и переходят в корневые отложения, которые могут быть представлены несколькими пластами различных солей. Корневые отложения уже не участвуют в годовом цикле высаживания-растворения солей. Их образованию благоприятствует морозное выветривание горных пород, в результате которого образуется значительная масса мелкодисперсных частиц. Продукты выветривания сносятся в озера, где образуют терригенные и иловые отложения, которые перекрывают слои соли. В результате протекания сложных процессов концентрирования растворов летом и зимой, высаживания из раствора различных труднорастворимых соединений в Западном Забайкалье сформировалось несколько очагов континентального засоления (рис.1) [Plyusnin, Peryazeva, 2005].

На рисунке 2 приведены диаграммы анионного состава обследованных нами минерализованных озер Западного Забайкалья. Исследованные озера разделились на две группы: 1) с преимущественно гидрокарбонатно-карбонатным анионным составом, куда входят озера с содержанием $\mathrm{HCO}_{3}+\mathrm{CO}_{3}$ от 53 до 99 экв.\%. 2) с преимущественно сульфатным анионным составом, с содержанием $\mathrm{SO}_{4}$ от 59 до85 \%. Разделение анионного состава вод на две хорошо выраженные группы указывает на существование принципиально разных условий метаморфизации химического состава вод в регионе. Среди минеральных озер чаще встречаются водоемы, в которых заключена вода содового типа. Наиболее минерализованные озера с содовым типом вод располагаются в степных ландшафтах. Этот тип вод встречается и в лесостепных ландшафтах, но здесь озера содержат воду с общей минерализацией менее 1 г/л. Преимущественно сульфатный тип вод формируется только в двух местах. В Баргузинской межгорной впадине такой тип имеют воды, заключенные в группе Алгинских озер. Из этой группы нами были изучены Большое, Малое Алгинские озера и озеро Гуджирчан. В этой группе насчитывалось семь озер, но в последние годы в связи с засухой, малые озера пересохли, места их былого расположения фиксируются отложениями гидрогенных солей. В ГусиноозерскоОронгойской впадине сульфатный тип вод имеют озера Сульфатное, Степное, Белое и несколько малых озер расположенных в их окрестностях.

\section{ФОРМИРОВАНИЕ ХИМИЧЕСКОГО \\ COCTABA \\ СУЛЬФАТНЫХ МИНЕРАЛЬНЫХ ОЗЕР БАРГУЗИНСКОЙ ВПАДИНЫ}


Известно, что территория Баргузинской впадины характеризуется интенсивной разгрузкой азотных термальных вод. Источники термальных вод, в основном, фиксируются в прибортовых частях впадины. На границе с Баргузинским хребтом, который ограничивает впадину с запада, разгружаются гидротермы с преимущественно гидрокарбонатным анионным составом, а термальные источники, располагающиеся у подножия Икатского хребта, характеризуются сульфатным типом воды [Плюснин и др., 2013]. Среди родников связанных с Икатским хребтом выделяется Алгинский источник, разгрузка которого происходит в юго-восточной части Баргузинской впадины в хорошо выраженном местном понижении рельефа (рис.3). С его разгрузкой связывается формирование ресурсов и химического состава группы Алгинских минеральных озер [Дзюба и др.,1999].

На космоснимке, приведенном на рисунке 3, можно заметить, что источник и озера располагаются в пределах единого опущенного блока пород, который имеет резкие границы с окружающей территорией. В то же время сам родник не имеет хорошо выраженной котловины вымывания, дебит его небольшой и составляет всего по нашим измерениям 0,1 л/с. Источник с таким дебитом не может оказать существенного влияния на ресурсы и химический состав озер. Нам представляется, что питание озер происходит за счет разгрузки трещинно-жильных вод по разломам расположенным под их акваторией и на окружающей территории. Разгрузка трещинно-жильных вод, вероятно, происходит по всей площади этого блока, так как вся территория в окружении озер и источника заболочена. Химический состав трещинно-жильных вод близок составу, установленному в термальном источнике, поэтому отправной точкой для определения степени метаморфизации воды в озерах будем использовать состав воды в источнике (табл. 1). Для озерных вод характерна слабощелочная реакция среды, только в исключительных случаях $\mathrm{pH}$ достигает значений более девяти. В этих условиях происходит трансформация состава озерных вод по сульфатному направлению. Преобладание в анионном составе сульфатиона определяет устойчивость в воде кальция, так как при испарительном и морозном концентрировании не достигается насыщения относительно его сульфатных солей. Кальций не удаляется полностью из растворов, а присутствует в озерах в значимых концентрациях, создавая конкуренцию натрию. Процесс изменения химического состава воды в озерах носит сложный характер, так как погодные условия в районе не постоянны: меняется, количество выпадающих атмосферных осадков, средняя температура воздуха, интенсивность и направление ветра. Соответственно меняется соотношение вклада в ресурсы озер трещинно-жильных, поверхностных и атмосферных вод. Меняется интенсивность испарительного и морозного концентрирования растворов и осаждение аутигенных минералов.

Максимальная минерализация воды нами была установлена в оз. Гуджирчан, в 2010 г. она достигла 81,3 г/л. В это время в растворе зафиксированы максимальная концентрация натрия и минимальная - кальция, $\mathrm{pH}$ вод достиг значения 9,06. Н.А. Власовым в 1954 году была определена сумма солей в озере Гуджирчан в 107,67 г/л, в это время преобладающей солью в минеральном составе был сульфат натрия. Зимой из раствора высаживался мирабилит. Дно озера Гуджирчан покрыто слоем ила мощностью 30-40 см, перемешанного с кристаллами мирабилита. Под слоем ила залегает пласт мирабилита мощностью до 3,5 м. Садка мирабилита происходит из высоко концентрированных растворов в зимнее время [Минеральные воды..., 1961]. Значительно чаще в озерах достигается насыщение относительно карбонатов кальция и магния. В 
верхнем 40 сантиметровом слое ила установлено образование кальцита, низкомагниевого кальцита, содержание этих аутигенных минералов в илистых отложениях достигает 4045\% [Солотчина и др., 2013, Солотчин П.А. и др., 2017]. В донных отложениях озер сформировалась восстановительная обстановка, происходит восстановление сульфат-иона до сероводорода, отложение сульфидов железа. На берегу озера Гуджирчан происходит отложение гидрогенных солей, которые покрывают глинистые отложения сплошным ковром, минералогический анализ солей показал присутствие таких минералов как астраханин $\left(\mathrm{Na}_{2} \mathrm{SO}_{4} \mathrm{MgSO}_{4} 4 \mathrm{H}_{2} \mathrm{O}\right)$, энаргит $\left(\mathrm{Cu}_{3} \mathrm{AsS}_{4}\right)$.

При образовании твердых фаз соответственно изменяется химический состав озерной воды и рН. Связанную с этими процессами дисперсию в измеренных параметрах, мы зафиксировали в озерах при опробовании в разные годы. В источнике термальных вод в месте разгрузки не достигается насыщения относительно карбонатов и других соединений, поэтому концентрация растворенных веществ остается относительно постоянной (табл. 1).

Так как водосборная площадь озер небольшая, нами предполагается, что принос растворенных веществ в озера происходит, в основном, только за счет разгрузки трещинно-жильных вод и выпадения атмосферных осадков. Минерализация атмосферных осадков небольшая и какого-либо изменения в химический состав воды заключенной в озерах они не вносят. Во влажные годы они разбавляют озерные воды, и процессы аутигенного минералообразования прекращаются. Главный вклад в формирование химического состава воды, заключенной в озерах вносят трещинно-жильные воды, их компонентный состав соответствует исследованному термальному источнику. Для выявления степени концентрирования растворенных веществ в озерных водах использованы устойчивые в растворе компоненты. Наиболее подходящим химическим элементом для этой цели является хлорид-ион. Он устойчив в растворе в широком диапазоне концентраций, не образует в рассматриваемых условиях труднорастворимых соединений и количественно определяется в этом типе вод. Путем нормирования содержаний хлорида в озерах по отношению к его концентрации в источнике установлено, что хлорид-ион накапливается во всех обследованных минеральных озерах. В Большом Алгинском озере за счет испарения и вымораживания воды происходит концентрирование растворенного хлорида в разные годы в 2,4-24,0 раза, в Малом Алгинском озере в 62,8 раз, а в озере Гуджирчан в разные годы в 95-154,4 раз (табл. 1). Степень испарительного концентрирования растворов в рассматриваемых озерах, вероятно, связана с различной долей атмосферных и поверхностных вод участвующих в формировании их ресурсов.

Почти также интенсивно накапливаются в воде озер при испарительном концентрировании и вымораживании растворителя сульфат-ион и магний. Степень концентрирования натрия в озере Гуджирчан выше чем хлорид-иона. Это возможно связано с дополнительным приносом этого элемента поверхностными водами с водосборной площади озера в составе гидрокарбонатных солей. Содержания других компонентов в растворе при испарительном концентрировании растут не так интенсивно, а содержание кальция в минеральных озерах становится ниже, чем в воде термального источника. Изменение соотношения между растворенными компонентами в системе озеро-источник происходит за счет образования твердых фаз. В озерных водах достигается равновесие растворенных веществ относительно гидроокислов железа, кальцита, глин, и др. труднорастворимых соединений. Содержание фторид-иона в озерах возрастает не столь интенсивно, как хлорида, максимальное концентрирование в растворе наблюдается в 
озере Малое Алгинское, которое располагается вблизи термального источника, здесь содержание достигает 19,2 мг/л. В других озерах, в том числе и в озере Гуджирчан, в котором установлена максимальная минерализация воды, его концентрация ниже. Вероятно, этот ион не может сильно концентрироваться в сульфатных водах, так как в них всегда присутствует относительно высокие концентрации кальция, и он выводится из раствора в результате кристаллизации флюорита. Ранее нами было показано, что в азотных термальных водах равновесие с флюоритом достигается уже при минерализации 0,2-0,3 г/л, если рН воды > 8,2 [Шварцев и др., 2015]. В то время как в содовых минеральных озерах, где в растворе значительно меньше кальция, концентрация фторида может достигать 414 мг/л [Борзенко, Фёдоров, 2018].

Содержание микроэлементов в озерах расположенных в рассматриваемых очагах засоления возрастает не пропорционально степени концентрирования. В таблице 2 представлены результаты анализа микроэлементов в озерах в сравнении с содержанием их в источнике.

Самая высокая степень концентрирования в сульфатных озерах установлена для микроэлементов образующих в растворе анионы. Наибольшей степенью концентрирования в озерах характеризуется бор. В озере Гуджирчан установлено концентрирование этого компонента в 194 раза. Для мышьяка концентрирование составляет 165, для фосфора 112 раз по сравнению с водами в источнике. При этом для бора и мышьяка определены наивысшие абсолютные содержания для минерализованных озер Забайкалья. Это связано с тем, что в азотных гидротермах, которые, в основном, поставляют растворенные вещества в озера, отмечаются их значительные содержания. С этим же связано установленное обогащение воды сульфатных озер вольфрамом. Изначально высокие содержания этого элемента в гидротермах приводят к тому, что в результате протекания процессов испарительного и морозного концентрирования в озерах, они достигают миллиграммовых значений. В рассматриваемых сульфатных озерах в значительных концентрациях обнаруживаются и тяжелые металлы - $\mathrm{Ni}, \mathrm{Cu}, \mathrm{Pb}, \mathrm{Cd}, \mathrm{Bi}$, что также объясняется их высокими концентрациями в трещинно-жильных водах, за счет которых формируются ресурсы озер [Справочник, 1990; Плюснин и др., 2008; Doroshkevich et.al., 2017].

В озерах наблюдается небольшой рост концентрации РЗЕ по сравнению с источником (табл. 3). С ростом минерализации озерных вод вначале возрастает доля легких редкоземельных элементов, затем соотношение между легкими и тяжелыми РЗЕ выравнивается. Так в пробах воды источника Алгинский содержание $\sum$ ЛР3Э (La-Eu) составляет 91\%, в оз. Б. Алгинское - 95,8\%, в о3. М. Алгинское 92,3\% от общего содержания Р3Э. Показатель отношения $(\mathrm{La} / \mathrm{Yb})_{\mathrm{N}}$ варьирует в весьма значительных пределах от 0,64 в источнике до 7,65 в озере Б. Алгинское. Эти изменения отражают воздействие на поведение редкоземельных элементов в растворе нескольких факторов. Среди наиболее значимых необходимо указать окислительно-восстановительные и кислотно-основные условия, форму нахождения элементов в растворе, интенсивность образования аутигенных минералов. Известно, что основной формой миграции многих редкоземельных элементов в растворе являются карбонатные комплексные соединения, в связи с тем, что в рассматриваемых водах карбонат-иона очень мало, эта форма нахождения элементов не играет большой роли и содержание многих элементов не высоки. Наиболее весомый вклад этой формы миграции РЗЕ наблюдается в озере 
Гуджирчан, где $\mathrm{pH}>$ 8,3 и в растворе в значимых количествах присутствует карбонат-ион. Здесь содержание некоторых РЗЕ в водах возрастает.

\section{СУЛЬФАТНЫЕ МИНЕРАЛЬНЫЕ ОЗЕРА ГУСИНООЗЕРСКО-ОРОНГОЙСКОЙ МЕЖГОРНОЙ ВПАДИНЫ}

Вторая группа сульфатных озер Западного Забайкалья располагается в Гусиноозерско-Оронгойской впадине мезозойского возраста. Эта межгорная впадина располагается в центральной части Западного Забайкалья и ограничена на северо-западе Хамбинским, а на юго-востоке Моностойким хребтами. На территории господствует резко континентальный климат, который характеризуется отрицательными показателями среднегодовых температур $\left(-2,-3^{\circ} \mathrm{C}\right)$, коротким периодом безморозных дней (95-100), сравнительно небольшим количеством атмосферных осадков (200-300 мм). Отрицательная среднемесячная температура воздуха сохраняется в течение 6 месяцев, озера промерзают на значительную глубину (до 1,2-1,4 м) [Обожин, 1984].

Минеральные озера располагаются в бессточных микрокотловинах, где за счет испарения и вымораживания воды происходит концентрирование веществ в растворе.

Геолого-гидрогеологическая характеристика района. Гусиноозерско-Оронгойская межгорная впадина входила в рифтовую систему, существовавшую на этой территории в мезозое. Здесь широко распространены покровы щелочных и умеренно-щелочных базальтов. Магматические расплавы были обогащены калием, натрием, фтором, хлором, серой, стронцием, литием, молибденом, никелем, ванадием.

Геологической особенностью рассматриваемого района является наличие в северозападном борту Гусиноозерско-Оронгойской и Иволгинской впадин проявлений карбонатитов, которые сформировались в позднем мезозое [Рипп и др., 1999]. Карбонатиты представлены дайками, плащеобразными залежами и крутопадающими телами брекчий, они связаны с щелочно-основными высококалиевыми породами и относятся к редкоземельному (Аршанское, Южное проявления) и существенно барийстронциевому (Халюта, Ошурково) типам. Проявления карбонатитов характеризуются высоким содержанием сульфатной серы. Содержание сульфатных минералов в них нередко достигает 20-30\%. В пределах Халютинского поля карбонатитов валовое содержание $\mathrm{SO}_{3}$ составляет 2,85-13,6, Ошурковского 0,68-8,82, Аршанского 1,42-10,82, Южного 0,83-3,08\%. Среди сульфатных минералов выявлено необычайно высокое распространение хорошо растворимых в воде сульфатов натрия и калия. В связи с этим на выше названных участках на поверхности карбонатитов наблюдается кавернозность, связанная с выщелачиванием хорошо растворимых сульфатов щелочных металлов [Дорошкевич и др., 2003]. Из устного сообщения Г.С. Риппа известно, что сульфаты щелочных металлов легко извлекаются из карбонатитов путем выщелачивания дистиллированной водой. Исследованный им изотопный состав серы в этих вытяжках показал, что $\delta^{34} \mathrm{~S}_{\mathrm{CDT}}$ составляет 10,9; 11,7; 12,6 .

Гусиноозерско-Оронгойская впадина заполнена континентальными осадками. В их составе присутствуют литологически различные породы - от крупно галечных конгломератов и разнозернистых песчаников до алевритов и углей, относящихся к гусиноозерской серии нижнего мела [Борисенко и др., 1994; Булнаев, 2006; Лунина, 2009]. Отложения гусиноозерской серии разделены на четыре свиты (снизу): муртойскую, убукунскую, селенгинскую и холбольджинскую. Все четыре свиты залегают согласно одна на другой. Муртойская свита залегает на вулканитах ичетуйской свиты. 
Тектонические условия определяются тем, что район располагается в пределах простирания Джидино-Витимского структурного шва, разделяющего области мезозойской и кайнозойской тектономагматических активизаций. Тектонический шов был активен на протяжении длительного времени. Сформировавшиеся здесь глубинные региональные разломы, имеют северо-восточное простирание и представляют собой участки повышенной трещиноватости, раздробленности, брекчирования, катаклаза и милонитизации пород. Во внутреннем поле впадины отмечается несколько поперечных сбросов, ориентированных обычно на северо-запад и имеющих плоскости разрывов, близкие к вертикальным [Тектонические..., 1978]. Главным образом они представлены сбросами и сдвиго-сбросами и образовались в условиях растяжения. В их пределах водообильность отложений возрастает на несколько порядков, особенно она большая на пересечение двух и более разломов [Борисенко и др., 1990].

Во впадине выделяется три основных водоносных комплекса: 1. Четвертичные отложения с порово-пластовыми грунтовыми водами. Водовмещающими породами являются галечники, пески и супеси. Воды эти обычно залегают на глубине $2-4$ м, редко достигают 22 м. Питание этих вод осуществляется за счет атмосферных осадков, поверхностных вод, подземных вод угленосной толщи и вод кристаллических пород. Воды комплекса, в основном, пресные гидрокарбонатного кальциево-магниевого состава; 2. Отложения гусиноозерской серии характеризуются развитием пластовых и пластовотрещинных вод. Воды, заключенные в породах муртойской и убукунской свит, по химическому составу гидрокарбонатные натриевые с минерализацией до 0,5 г/л. Породы селенгинской свиты содержат сульфатно-гидрокарбонатные кальциево-натриевые воды с минерализацией до 2,2 г/л (табл. 4). Питание водоносного комплекса происходит за счет атмосферных осадков и трещинных вод кристаллических пород. З. Кристаллическое основание, представлено гранитоидами палеозойского и мезозойского возраста и комплексом эффузивов триасового периода мезозоя. Наибольшей водообильностью и фильтрационными свойствами обладают зоны тектонических нарушений, которые служат основными каналами движения подземных вод. По разломам происходит разгрузка вод в виде восходящих родников [Борхонова, 2006]. В пределах расположения нижнемеловых отложений вода родников содержит до 693 мг/л сульфат-иона и до 212 мг/л хлорид-иона.

Озеро Сульфатное. Озеро располагается в микровпадине тектонического происхождения в междуречье рек Загустай и Убукун (рис. 4). В этой впадине располагается пять крупных и несколько мелких озер. Поверхность впадины имеет наклон в юго-восточном направлении в сторону долины реки Убукун. В северной и северозападной части этой впадины озера пресные. Они располагаются на границе гидрогеологического массива и межгорной впадины. Питание их осуществляется поверхностным и подземным стоком с гидрогеологического массива, представленного Хамбинским хребтом. Разгрузка происходит слабым поверхностным и подземным стоком в юго-восточном направлении через систему проток в реку Убукун. На космоснимке направление стока проявляется яркой зеленой растительностью (рис. 4). На озеро Сульфатное эти воды не оказывают сколько-нибудь значимого влияния. Котловина этого озера располагается южнее в центральной части микровпадины, она обособлена от пресных озер перемычкой. Котловина вытянута в северо-западном направлении, ее поверхность по сравнению с окружающей территорией заглублена на 50-60 м (абс. отм. 593 м) Несомненно, котловина этого озера имеет тектоническое происхождение. На космоснимках дешифрируются разломы северо-западного простирания, берега озера 
имеют прямолинейный характер. Водосборная площадь этого озера небольшая и не способна обеспечить его существование длительное время. Между тем это озеро постоянно существует за период наблюдения, который составляет более ста лет. В питании озера большое значение имеют артезианские воды. В юго-восточной части микрокотловины разгружается источник. Здесь же пробурено три мелкие скважины, использовавшиеся ранее для поения скота (рис. 4). Родник и первая скважина, вероятно, дренируют грунтовые воды, они характеризуются малой минерализацией, гидрокарбонатным натриевым типом вод. А скважины 2 и 3 вскрыли глубинные воды. В отобранных пробах воды в анионном составе резко возросли содержания сульфат-иона, а в скважине 3 и хлорид-иона. Результаты исследования химического состава этих вод приведены в таблице 5.

В воде родника и скважины 1 основным анионом является гидрокарбонат с долевым содержанием 85 и 86 мг-экв.\%. Относительные количества сульфат-иона и хлорид- иона варьируют в пределах 8,8 - 9,5 и 3.2-4.0 мг-экв.\% соответственно. Среди катионов основным является натрий, долевое содержание которого составляет 74 и 63,4 мг-экв.\%, долевые содержания кальция 12 и 28,4, магния 14,1 и 8,1 мг-экв.\%. Изученные пробы воды родника и скважины 1 относятся к гидрокарбонатному натриевому химическому типу. В воде скважины 2 долевое содержание сульфата преобладает и составляет 52,7, гидрокарбоната - 43,3, хлорид-иона - 2,4 мг-экв.\%. Среди катионов доминирует натрий с относительным содержанием 80,1 мг-экв.\%, относительные содержания кальция и магния составляют 8,8 и 10,4 мг-экв.\%. В воде скважины 3 долевые содержания гидрокарбонатов и сульфатов находятся в сопоставимых количествах и составляют 42,4 и 38,2 мг-экв.\%, хлорид-иона - 13,2 мг-экв.\%. Среди катионов основным является натрий с долевым содержанием 78,12 мг-экв.\%, относительные количества кальция и магния составляют 12,3 и 9,6 мг-экв.\%. Полученные результаты позволяют отнести воды скважин 2 и 3 к гидрокарбонатно-сульфатному и сульфатногидрокарбонатному натриевому химическим типам.

Воды, вскрытые скважинами 2 и 3, вполне могут принимать участие в питании Сульфатного озера, так как мощность водоупорных пород небольшая. Вероятно, основное питание происходит за счет разгрузки глубинных напорных вод по глубоко залегающим разрывным нарушениям непосредственно в котловину озера.

Озера Белое и Степное. Озера располагаются в наиболее низкой части Гусиноозерско-Оронгойской впадины. Поверхность воды озера Белое имеет абсолютную отметку 521м, а озера Степное 517 м. В месте расположения минеральных озер рельеф представляет собой ровную площадку со слабым уклоном в восточном, юго-восточном направлении. На рисунке 5 приведен космоснимок этой территории с дешифрированными разломами. Видно, что озера располагаются в узлах пересечения разломов северовосточного направления с секущими их разломами северо-западными и субмеридионального направлений. Разломы северо-восточного направления сбросового типа. Наиболее интенсивный сброс блока пород в этом месте произошел по северному разлому. Здесь мы наблюдаем на расстоянии 1,5 км перепад высот между озерами Торма и Белое в 21 м. Этот разлом очень хорошо выражен в рельефе в виде уступа. Разлом, в пределах которого находится озеро Степное, выделяется в рельефе лощиной, которая протягивается в северо-восточном направлении. Она имеет абсолютные отметки рельефа ниже окружающей территории на 2-3 м. Следующей ступенью системы разломов сбросового типа в этом районе является разрывное нарушение, по которому заложено 
русло реки Селенга. В этом месте русло реки имеет северо-восточное направление, располагается параллельно выделенным нами двум разломам. Уровень воды в реке находится на отметке 514 м. Нам представляется, что сбросовые нарушения гидравлически связаны друг с другом, по ним близко к поверхности поднимаются подземные воды, заключенные в юрских отложениях. А в местах пересечения поперечными разломами, где породы интенсивно раздроблены и хорошо проницаемы, глубинные воды разгружаются на поверхность и питают озера. Область создания напора глубинных вод находится на границе гидрогеологического массива и межгорной впадины в северо-западной части рассматриваемой территории, которая располагается на значительно более высоких абсолютных отметках.

Кроме этих двух озер на рассматриваемой территории имеются и другие мелкие водопроявления, в которых заключена минерализованная вода (оз. Талын-Нур и др.). Определяющим фактором образования соленых озер является опускание этого блока пород и, в связи с этим, подъем глубинных вод к поверхности по разрывным нарушениям. О химическом составе глубинных вод, заключенных в юрских отложениях можно судить по данным опробования скважины 513, пробуренной Селенгинской ГРЭ в 1996 г. (табл. 6). Глубина скважины составляет 504 м, породы, вмещающие подземные воды в пределах опробованных интервалов, представлены алевролитами, аргиллитами и песчаниками.

Видно, что в водоносных горизонтах с глубиной наблюдается рост общей минерализации подземных вод и возрастание доли сульфат-иона. Содержание сульфатиона увеличивается с 43,3 экв.\% в верхнем водоносном горизонте, до 74,5экв.\% в среднем и 80,3 экв.\% в нижнем. Это выражается и в росте отношения сульфат-иона к хлорид-иону, т.е. с глубиной происходит разделение этих анионов - обогащение вод сульфатом и обеднение хлоридом. С глубиной наблюдается также и рост содержания кальция, его доля увеличивается с 7,2 экв.\% в верхнем водоносном горизонте до 12,5 экв.\% в среднем и 15,6 экв\% в нижнем. Это, вероятно, происходит вследствие накапливания в растворе сульфата, так как произведение растворимости сульфата кальция значительно выше, чем у карбоната кальция. Относительное содержание магния остается на одном уровне, а его абсолютные содержания достигают в озере Степном граммовых значений. Нижний водоносный горизонт наиболее водообилен (табл. 6), из него по разрывным нарушениям, вероятно, и поступают глубинные воды в озера.

Макро- и микрокомпонентный состав воды озер. Сульфатные озера, расположенные в Гусиноозерско-Оронгойской впадине, по концентрации солей отличаются широкой вариабельностью от 3,5 до 30,8 г/л (табл. 7). Максимальная концентрация солей отмечена в оз. Степном. Геохимическая среда характеризуется как слабо щелочная, значения $\mathrm{pH}$ изменяются от 8,47 до 8,79. Вода минеральных озер характеризуется значительной жесткостью, которая создается не столько кальцием, а в более значительной степени магнием. Высокие содержания магния является отличительной чертой этой группы озер. По этому параметру они резко отличаются от сульфатных озер Баргузинской впадины.

По классификации О. А. Алекина (1970) вода рассматриваемых озер относится к сульфатному натриевому типу. Максимальная доля сульфат-иона характерна для воды озера Степное (81,8 мг-экв.\%), в воде озера Белое сульфата содержится 58,1 мг-экв.\%, а в воде озера Сульфатное 55,5 мг-экв.\%. Доля хлорид-иона наиболее значительна в воде оз. Сульфатное и составляет 31,2 мг-экв.\%. В катионном составе воды озер доминирует натрий, его доля составляет 59,1 и 62,4 мг-экв.\% в озере Степном и Белом, а в Сульфатном 
достигает 82,1 мг-экв.\%. Вторым по значимости катионом в составе воды озер является магний, его доля изменяется от 39,8 мг-экв.\% в озере Степном, 33,6 мг-экв.\% в озере Белом и 16,5 мг-экв.\% в озере Сульфатном.

В сульфатных озерах наблюдаются относительно высокие содержания лития, стронция, бора. Но в целом, несмотря на высокую минерализацию, концентрация микроэлементов в сульфатных озерах относительно низкая (табл. 8).

В сульфатных озерах Белое и Сульфатное наблюдается абсолютное преобладание легких лантаноидов над тяжелыми (табл. 9). Лантан, церий, празеодим дают основной вклад в суммарное значение. Другое распределение лантаноидов наблюдается в озере Степное. В нем наблюдается относительное уменьшение содержания празеодима и возрастание содержания эрбия. Такие резкие различия в распределении редкоземельных элементов, на наш взгляд, указывают на то, что питание этих озер происходит за счет подземных вод из различных водоносных горизонтов с разной историей формирования химического состава воды. Нормированные распределения РЗЭ характеризуются четко выраженной отрицательной цериевой аномалией $\left(\mathrm{Ce} / \mathrm{Ce}{ }^{*}\right)_{N}=0,1-0,85$ и положительной европиевой аномалией $\left(\mathrm{Eu} / \mathrm{Eu}^{*}\right)_{\mathrm{N}}=3,99-22,57$. Показатель отношения нормированных значений $(\mathrm{La} / \mathrm{Yb})_{\mathrm{N}}$ увеличивается с ростом минерализации воды от 0,79 оз. Белое $(6,98$ г/л) до 4,94 оз. Сульфатное (16,27 г/л) и 1,06 оз. Степное (30,81 г/л).

Характеристика состава донных отложений. Рассмотрим состав донных отложений сульфатных озер в сравнении с пресными озерами, расположенными на этой территории (табл. 10). Такое сравнение позволит выявить процессы, в результате протекания которых образуется своеобразный химический состав донных отложений при сульфатном засолении.

Анализ данных приведённых в таблице 10 показывает, что в соленых озерах содержание оксидов кремния, алюминия, железа, калия почти в два раза меньше, чем в пресных озерах. А содержание оксидов кальция и магния почти в 2-3 раза больше, чем в пресных озерах. В соленом озере Белое в донных отложениях установлена высокая доля потерь при прокаливании, а в Сульфатном озере донные отложения имеют относительно высокое содержание натрия. В пресных озерах выделяется ассоциация элементов Fe-Al-TiMg-K-P. Выделенные элементы характеризуются высокими положительными корреляционными связями внутри ассоциации $\left(K_{к о р}=0,82-0,94\right)$ и устойчивыми отрицательными связями с кремнием $\left(K_{\kappa o p}=-0,82 \ldots-0,94\right)$, что связано с накоплением глинистых минералов и гидроксидов железа, марганца и алюминия в верхнем слое донных отложений.

В микроэлементном составе соленых и пресных озер имеются существенные различия. В донных отложениях соленых озер содержания Sc, V, Cr, Co, Zn, Pb, Rb в 1,52,5 раза меньше, чем в пресных озерах (табл. 11). Эти элементы связаны с терригенными отложениями, которые сносятся с окружающей территории. В минеральных озерах их мало, т.е. вклад сноса продуктов выветривания с окружающей территории значительно меньше. В донных отложениях здесь господствуют осадки, формирующиеся в озере. С ними связаны установленные повышенные содержания брома. Поступление этого элемента в озеро, вероятно, связано не с выветриванием пород на водосборной территории, а с выщелачиванием его подземными водами из осадочных пород, заполняющих впадину и из угольных пластов. В донных отложениях оз. Сульфатное установлены высокие содержания стронция, распределение его содержания в донных отложениях коррелирует с концентрацией кальция $\left(K_{\text {кор }}=0,72-0,82\right)$. Вероятно, он попадает 
из раствора в донные отложения при высаживании аутигенных карбонатов. Формирование аутигенных минералов происходило в разнообразных геохимических условиях связанных с изменением климата. За последние 6,6 тыс. лет в озере Сульфатное в 56 см слое ила отлагались, в основном, карбонаты кальция и магния [Солотчин и др., 2017]. Из других групп минералов в илистых донных отложениях эпизодически встречается гипс. В южной части озера под слоем ила залегают пластовые отложения мирабилита мощностью до 3 м [Минеральные воды..., 1961].

Исследование минерального состава донных отложений рентгено-структурным методом показало, что в составе осадков озер Белое и Сульфатное в значимых количествах присутствуют карбонаты кальция и магния. В отложениях оз. Белое диагностированы анкерит $\mathrm{Ca}(\mathrm{Fe}, \mathrm{Mg})\left(\mathrm{CO}_{3}\right)_{2}$, кальцит $\left(\mathrm{CaCO}_{3}\right)$, магнезит $\left(\mathrm{MgCO}_{3}\right)$. На берегу озера Белое ранее был обнаружен беркеит $\left(\mathrm{Na}_{6}\left(\mathrm{CO}_{3}\right)\left(\mathrm{SO}_{4}\right)_{2}\right.$ [Дорошкевич и др., 2003]. В донных отложениях оз. Сульфатное нами диагностированы кальцит и магнезит.

В пресных озерах донные отложения, представлены кварцем (до 45-50 \%), плагиоклазом (до 25-30\%), калиевым полевым шпатом (до 15-20\%). Глинисто-слюдистые агрегаты представлены биотитом (до 41\%), мусковитом (до 6,2-7,8\%), хлоритом (до 1,2\%).

\section{ОБСУЖДЕНИЕ ПОЛУЧЕННЫХ РЕЗУЛЬТАТОВ}

Из представленных материалов исследования можно видеть, что сульфатные минеральные озера представляют собой уникальные природные образования. Они формируются в исключительных природных условиях. Для их образования необходимо сочетание нескольких факторов. Одним из наиболее важных является источник дополнительного поступления серы. В Западном Забайкалье озера этого химического типа образуются под воздействием разгрузки сульфатных натриевых подземных вод.

В Баргузинской впадине сульфатные озера образуются в результате разгрузки термальных трещинно-жильных вод относящихся к сульфатному натриевому химическому типу. Этот тип вод формируется преимущественно в пределах Икатского хребта, ограждающего впадину с юго-востока [Плюснин и др., 2013]. Разгружающиеся в этом месте гидротермы характеризуются тяжелым изотопным составом серы - в Алгинском источнике $\delta^{34} \mathrm{~S}$ равно 28,7 CDT, Инском - 24,0, в Сеюйском - 22,6. Такой изотопный состав серы в гидротермах унаследован от горных пород, в пределах которых формируют ресурсы трещинно-жильные воды этого района. Ранее нами было сделано предположение, что поступление серы в трещинно-жильные воды связано не с окислением сульфидных минералов, которые часто присутствуют в горных породах, а растворением сульфатных минералов, которые могут присутствовать в метаморфогенно-осадочных образованиях [Плюснин и др., 2008; Шварцев и др., 2015]. Геологической особенностью пород, которые слагают Икатский хребет, является присутствие кембрийских карбонатных отложений, сформировавшихся в морских условиях. Формирование пород происходило в условиях задугового морского бассейна [Беличенко и др., 2006]. Это объясняет присутствие в них серы в сульфатной форме с тяжелым изотопным составом. Икатский массив карбонатных пород прослеживается на протяжении 29 км, ширина в отдельных местах достигает 7 км, мощность сотни метров. Тектоническими движениями массив разделен на блоки. Везде в коренных выходах известняка наблюдаются поверхностные формы карста в виде каверн размером от первых миллиметров до десятка сантиметров. В этом районе выявлено шесть пещер, карстовая воронка, высокодебитные источники карстовых вод (до 40 л/с) [Васильев, Морозов, 2013]. В одной из пещер обнаружены кристаллы кальцита в виде 
призм и скаленоэдров, которые покрывают стены и пол. Форма кристаллов указывает на то, что они формировались из растворов. Икатский хребет находится в зоне сплошного распространения многолетнемерзлых пород, мощность мерзлоты на водоразделах достигает 500-600 м [Байкал. Атлас, 1993]. В жидком состоянии здесь может находиться только термальная вода. На воздействие гидротерм указывает и температурный режим, установившийся в пещерах - у входа даже летом господствует отрицательная температура, пол покрыт льдом, а в глубине пещеры температура положительная и вода находится в жидком состоянии. Вероятно, пещеры сформировались потоком термальных вод, движущимся по разломам, при этом вблизи поверхности пустоты под воздействием отрицательных температур воздуха, господствующих на этой территории большую часть года, заполнились льдом. Гидротермы, движущиеся по пустотам в известняке, насыщены относительно карбонатных минералов: кальцита, магнезита, сидерита и др. При формировании этих минералов из раствора удаляются ионы кальция, магния, карбонатион поэтому подавляющая часть вод имеет сульфатный натриевый состав. Вероятно, дебит этих термальных вод как всех карстовых вод значителен. Ресурсы термальных вод, разгружающихся в пределах Алгинских озер, подсчитать сейчас не представляется возможным, так как нет достоверных данных об субаквальной разгрузке. Но судя по мощности отложений мирабилита, которая только в районе озера Гуджирчан достигает 3,5 м, вклад сульфатных натриевых вод в ресурсы озер существенен.

Алгинские озера имеют нестабильный водный режим. Формирование карбонатных отложений в озере Б. Алгинское происходило неравномерно, за период в 4,9 тыс. лет наблюдалась неоднократная смена климатических условий, которые и проявились в неравномерной садке карбонатных минералов [Солотчина и др., 2013]. В исследованном разрезе наблюдается увеличение содержания карбонатных минералов от подошвы к кровле, что свидетельствует об усилении сухости климата. В настоящее время большинство озер Алгинской группы пересохло.

Установленные особенности микроэлементного состава воды, заключенной в озерах, непосредственно связаны с изначальным накоплением определенной группы химических элементов в гидротермах, состав которых формировался в процессе длительной фильтрации по трещиноватым породам и растворением их нагретыми водами. На заключительной стадии происходило концентрирование озерной воды, заключенной в бессточной котловине, в процессе испарения и вымораживания. Наиболее устойчивыми в растворе из микроэлементов оказались вольфрам и бор, которые присутствуют в виде вольфраматов и боратов натрия. Изначально высокие содержания вольфрама связаны с тем, что гидротермы взаимодействуют с шеелитовой минерализацией, которая установлена проводимыми здесь поисково-разведочными работами. В пределах Икатского хребта выявлено четыре месторождения вольфрама и ряд рудопроявлений [Васильев, Морозов, 2013; Государственная геологическая карта..., 2015].

В Гусиноозерско-Оронгойской межгорной впадине сульфатное засоление подземных и поверхностных вод сформировалось под воздействием разгрузки глубинных подземных вод из водоносных горизонтов юрских и меловых отложений.

Образование сульфатных натриевых вод в этих водоносных горизонтах, вероятно, имеет длительную историю. Окисление сульфидных минералов, распределенных в эндогенных породах, несомненно, дает какой-то вклад в формирование сульфатных вод, но этот вклад в их образовании не является определяющим. Окисление рассеянной сульфидной минерализации связано с выветриванием пород, поэтому в растворе 
накапливаются наряду с сульфат-ионом и другие анионы и катионы, образующиеся при гидролизе эффузивных и интрузивных пород. В результате протекания этих процессов в конечном итоге формируются содовые воды [Шварцев, 1998]. В сульфидах сера имеет легкий изотопный состав, и это соотношение между изотопами сохраняется при окислении их до сульфатов. Нами установлено, что в реке Цаган-Гол, которая формирует ресурсы в кристаллическом обрамлении Гусиноозерской впадины и где сульфат-ион образуется за счет окисления сульфидов, изотопное соотношение серы $\delta^{34} \mathrm{~S}_{\mathrm{VCDT}}$ составляет 3,8 \%. Тогда как в рассматриваемых очагах сульфатного засоления изотопный состав серы более тяжелый - в Сульфатном озере достигает 15,4 , в Белом - 15,9, в Степном - 12,3\%о $\delta^{34} \mathrm{~S}$ СDT.

Ранее нами было сказано о присутствии в рассматриваемом районе карбонатных пород. В отличие от сульфидов изотопный состав серы в карбонатитах более тяжелый. В барите карбонатитов Аршанского месторождения $\delta{ }^{34} \mathrm{~S}$ срт составляет 13,0 \%о, в баритоцелестине 13,2 \%о [Дорошкевич и др., 2003]. Эти изотопные отношения близки установленным значениям в воде сульфатных озер. Учитывая высокие содержания сульфатной серы в карбонатитах, можно предполагать их существенное воздействие на химический состав рассматриваемых подземных вод. Сульфаты натрия и калия до сих пор могут вымываться из карбонатитов атмосферными осадками, что доказано выщелачиванием их дистиллированной водой. За длительный период в раствор перешло большое количество сульфата, вероятно, часть его рассеялась. Но в мезозое в результате тектонических движений сформировались впадины и в них стали накапливаться минерализованные подземные воды с высоким содержанием сульфат-иона. Формированию подземного стока от мест расположения карбонатитов к центральной части впадины благоприятствовали сложившиеся тектонические условия, в том числе и широкое распространение поперечных разломов.

Вероятно, сульфатно-натриевая фаза карбонатитов была обеднена микроэлементами и, несмотря на то, что в результате её растворения формировались высокоминерализованные растворы, они были бедны микроэлементами. Вода, заключенная в сульфатных озерах Сульфатное, Белое, Степное, наследует эту изначально низкую концентрацию микроэлементов. В озерах, хотя и происходило концентрирование растворенного вещества за счет процессов испарения и вымораживания растворителя, и постепенно сформировался очаг сульфатного засоления, содержание микроэлементов остался низким. Из микроэлементов относительно высокими содержаниями в сульфатных озерах выделяется только стронций и литий, которые, вероятно, изначально присутствовали в расплаве сульфатной фазы карбонатитов. По этой же причине в озерах обнаруживаются и высокие содержания магния. Присутствие сульфат-иона в растворе определяет устойчивость в воде озер всех щелочноземельных элементов, в том числе магния и стронция. Но в тоже время в озерах постоянно высаживаются карбонаты, в первую очередь кальция. Лимитирующим фактором их образования выступает карбонатион. Его поступление в раствор связано с протекающими в озерах биогенными процессами и приносом поверхностных вод.

В озере Сульфатное проведены исследования образования карбонатных осадков до глубины 57 см [Солотчин и др., 2017]. На основании изотопных исследований показано, что озеро сформировалось 6,6 тысяч лет назад и, в течение всего времени его существования, было минеральным. Происходило высаживание карбонатов кальция и магния, изредка высаживался гипс. Выделено четыре стадии эволюции состава воды 
заключенной в озере, связанных с изменением климатических условий в регионе и его водным режимом.

Сульфатные озера располагаются в бессточных котловинах, где под воздействием испарения, вымораживания воды происходит концентрирование растворов и достигается равновесие относительно труднорастворимых соединений. Химический и рентгеноструктурный анализ донных отложений указывает на то, что при этом происходит высаживание различных карбонатных минералов. Проведенные нами расчеты равновесий по программе HidroGeo32 [Букаты, 1997] показали, что вода всех исследованных сульфатных озер находится в равновесии с такими карбонатными минералами как доломит, стронцианит (табл. 12). В большинстве исследованных озер достигается насыщение относительно кальцита и магнезита, за исключением озера Гуджирчан, Большое Алгинское, где фиксируются очень низкие содержания кальция и магния. Несмотря на высокое содержание сульфат-иона в воде озер ни в одном из них не достигается насыщения относительно сульфатных минералов. Очень далека от насыщения вода относительно мирабилита. Вероятно, садка этого минерала происходила в периоды времени, когда озера полностью перемерзали.

В донных отложениях сульфатных озер установлены низкие содержания лантана, церия, несмотря на то, что карбонатиты Аршанского проявления характеризуются высокими содержаниями редкоземельных элементов, носителями которых выступает бастнезит, паризит и алланит. Это связано с плохой миграцией редкоземельных элементов в растворах в сложившихся условиях. Химический состав сульфатных озер Гусиноозерско-Оронгойской впадины характеризуется низкими содержаниями микроэлементов, так как вода, заключенная в озерах, имеет невысокую степень взаимодействия с породой.

\section{ЗАКЛЮЧЕНИЕ}

В Западном Забайкалье сформировано два очага сульфатного засоления поверхностных и подземных вод. Определяющим фактором формирования сульфатного химического типа вод в озерах Западного Забайкалья, является то, что в их питании значительный вклад имеют подземные воды сульфатного натриевого типа.

На формирование сульфатных подземных вод в рассматриваемых районах оказывают влияние карбонатные горные породы, из которых в подземные воды выщелачивается сульфат-ион и натрий.

В минеральных озерах, которые располагаются в бессточных котловинах, происходит дальнейшая трансформация химического состава под воздействием испарительного концентрирования и вымораживания растворов. Достигается насыщение относительно карбонатов, минеральный состав которых определяется климатическими условиями. Садка мирабилита происходит в зимний период, когда озера перемерзают.

Микроэлементный состав минеральных озер определяется геохимическими условиями и историей формирования ресурсов и химического состава питающих их подземных вод. В озерах расположенных в Баргузинской впадине установлены высокие содержания бора, мышьяка, фосфора, вольфрама, тяжелых металлов. В сульфатных минеральных озерах Гусиноозерско-Оронгойской впадины несмотря на большую минерализацию воды, содержания микроэлементов низкие, за исключением стронция, лития, бора. 
Исследование выполнено в рамках государственного задания ГИН СО РАН по проекту IX.137.1.4. «Взаимодействие в системе..» № гос. рег. АААА-А17-117021310076-3, частично по проекту РФФИ № 18-45-030003\18.

\section{ЛИТЕРАТУРА}

Алекин О.А. Основы гидрохимии. Ленинград, Изд-во Гидрометеоиздат, 1970, 443 с.

Байкал. Атлас. Москва, Федеральная служба геодезии и картографии России, 1993. 160 c.

Беличенко В.Г., Гелетий Н.К., Бараш И.Г. Баргузинский микроконтинент (Байкальская горная область): к проблеме выделения // Геология и геофизика, 2006, т. 47 (10), с. $1049-1059$.

Борзенко С.В., Фёдоров И.А. Закономерности поведения некоторых микроэлементов в минеральных озерах Восточного Забайкалья // Успехи современного естествознания, 2019, № 1, с. 69-74.

Борзенко С.В. Основные особенности формирования состава вод минеральных озер Читино-Ингодинской впадины (Восточное Забайкалье) // Известия РАН. Серия географическая, 2014, № 4, с. 95-101.

Борисенко И.М., Адушинов А.А., Литвиненко Т.Е. Месторождения подземных вод горно-складчатых областей (на примере Прибайкалья и Западного Забайкалья). Москва, Изд-во Наука, 1990, 126 с.

Борисенко И.М., Пронин Н.М., Шайбонов Б.Б. Экология озера Гусиное. Улан-Удэ, Изд-во БНЦ СО РАН, 1994, 199 с.

Борхонова Е.В. Автореферат диссертации на соискание ученой степени кандидата геолого-минералогических наук. Улан-Удэ, 2006, 18 с.

Букаты М.Б. Разработка программного обеспечения в области нефтегазовой гидрогеологии // Разведка и охрана недр, 1997, № 2, с. 37-39.

Булнаев К.Б. Формирование впадин «забайкальского» типа // Тихоокеанская геология, 2006, т. 25, №1, с. 18-30.

Васильев О.А., Морозов О.Н. Пещеры Икатского карстового массива // Спелеология и спелестология, 2013, №4, с. 102-108.

Государственная геологическая карта Российской Федерации. М.: 1:200000. Лист N49-XVI (Карафтит) Объяснительная записка. Москва, Изд-во МФ ВСЕГЕИ, 2015, 102 с.

Дзюба А.А., Тулохонов А.К., Абидуева Т.И., Кулагина Н.В., Черных Л.А. Палеогеографические аспекты формирования соленых озер Баргузинской котловины // География и природные ресурсы, 1999, №2, с. 66-73.

Домрочева Е.В., Лепокурова О.Е. Равновесия содовых подземных вод угленосных отложений Нарыкско-Осташкинской площади (Кузбасс) с минералами вмещающих пород // Вестник Томского государственного университета, 2015, № 390, с. 211-217.

Дорошкевич А.Г., Кобылкина О.В., Рипп Г.С. Роль сульфатов в образовании карбонатитов Западного Забайкалья // Доклады Академии Наук, 2003, т. 388 (4), с. 535-538.

Замана Л.В., Борзенко С.В. Гидрохимический режим соленых озер Юго-Восточного Забайкалья // География и природные ресурсы, 2010, № 4, с. 100-107.

Иванов А.В., Трофимов Л.Н. Гидрохимия озер Центрального Забайкалья. Владивосток, Изд-во ДВНЦ АН СССР, 1982, 140 с. 
Леонова Г.А., Богуш А.А., Бобров В.А., Бычинский В.А., Трофимова Л.В., Маликов Ю.И. Эколого-геохимическая оценка соляных озер Алтайского края // География и природные ресурсы, 2007, №1, с. 51-59.

Лунина О.В., Гладков А.С. Разломно-блоковое строение и напряженное состояние земной коры Гусиноозерской впадины и прилегающей территории (Западное Забайкалье) // Геотектоника, 2009, №1, с. 78-96.

Минеральные воды южной части Восточной Сибири / Под редакцией Ткачук В.Г. и Толстихина Н.И. Москва-Ленинград, Изд-во АН СССР, 1961, т. 1, 346 с.

Моисеенко Т.И., Ганшина Н.А. Формирование химического состав вод озер в условиях изменения окружающей среды. Москва, Изд-во Наука, 2010, 275 с.

Обожин В.Н., Богданов В.Т., Кликунова О.Ф. Гидрохимия рек и озер Бурятии. Новосибирск, Изд-во Наука, 1984, 151 с.

Основы гидрогеологии. Гидрогеохимия. Новосибирск, Изд-во Наука, 1982, 286 с.

Плюснин А.М., Гунин В.И. Природные гидрогеологические системы, формирование химического состава и реакция на техногенное воздействие (на примере Забайкалья). Улан-Удэ, Изд-во Бурятского научного центра СО РАН, 2001, с.10.

Плюснин А.М., Замана Л.В., Шварцев С.Л., Токаренко О.Г., Чернявский М.К.

Гидрогеохимические особенности состава азотных гидротерм Байкальской рифтовой зоны // Геология и геофизика, 2013, т.54 (5), с. 647-664.

Плюснин А.М., Чернявский М.К., Посохов В.Ф. Условия формирования гидротерм Баргузинского Прибайкалья по данным микроэлементного и изотопного состава // Геохимия, 2008, №10, с. 1063-1072.

Посохов Е.В. Происхождение содовых вод в природе. Ленинград, Изд-во Гидрометеостат, 1969, 153 с.

Рипп Г.С., Ходанович П.Ю., Смирнова О.К. Новая карбонатитовая провинция в Западном Забайкалье // Геология и геофизика, 1999, т. 40 (1), с. 73-81.

Скляров Е.В., Склярова О.А., Меньшагин Ю.В., Данилова М.А. Минерализованные озера Забайкалья и северо-Восточной Монголии: особенности распространения и рудогенерирующий потенциал // География и природные ресурсы, 2011, № 4, с. 29-39.

Склярова О.А., Скляров Е.В., Федоровский В.С. Структурно-геологический контроль размещения и состава родников и озер Приольхонья // Геология и геофизика, 2002, т. 43 (8), с. 732-755.

Склярова О.А., Чудненко К.В., Бычинский В.А. Физико-химическое моделирование эволюции малых озер в условиях холодного климата // Геохимия, 2011, №8, с. 1-11.

Солотчин П.А., Скляров Е.В., Солотчина Э.П., Маркова Ю.Н. Карбонатная седиментация в малых минеральных озерах Западного Забайкалья: отклик на изменения климата голоцена // Доклады академии наук, 2017, т. 473 (6), с. 703-708.

Солотчина Э.П., Скляров Е.В., Солотчин П.А., Вологина Е.Г., Склярова О.А., Ухова Н.Н. Голоценовая осадочная летопись озера Большое Алгинское, Западное Забайкалье: связь с палеоклиматом // Доклады академии наук, 2013, т. 449 (1), с. 80-86.

Справочник по геохимии. Под ред. Г.В. Войткевич, А.В. Кокин, А.Е. Мирошников, В.Г. Прохоров. Москва, Изд-во Недра, 1990, 480 с.

Страховенко В.Д., Гаськова О.Л. Термодинамическая модель образования карбонатов и минеральных фаз урана в озерах Намши-нур и Цаган-тырм (Прибайкалье) // Геология и геофизика, 2018, т. 59 (4), с. 467-480. 
Страховенко В.Д., Школьник С.И., Даниленко И.В. Железомарганцевые конкреции пресноводных водоемов острова Ольхон (Байкал) и Кулундинской равнины (Западная Сибирь) // Геология и геофизика, 2018, т. 59 (2), с. 158-171.

Таран О.П., Болтенков В.В., Ермолаева Н.И., Зарубина Е.Ю., Делий И.В., Романов Р.Е., Страховенко В.Д. Взаимосвязь химического состава органического вещества озерных систем и генезиса сапропелей // Геохимия, 2018, № 3, с. 269-279.

Тектонические разломы Забайкалья // Труды БГИ СО РАН, вып. 22. Новосибирск, Изд-во Наука, 1978, 110 с.

Шварцев С.Л. Взаимодействие воды с алюмосиликатными горными породами: Обзор // Геология и геофизика, 1991, № 12, с. 16-50.

Шварцев С.Л. Геохимия содовых вод межгорного бассейна Датун провинция Шаньси, Северо-Западный Китай // Геохимия, 2006, № 10, с. 1097-1109.

Шварцев С.Л. Гидрогеохимия зоны гипергенеза. Москва, Изд-во Недра, 1998, 366 с.

Шварцев С.С., Замана Л.В., Плюснин А.М., Токаренко О.Г. Равновесие азотных терм Байкальской рифтовой зоны с минералами водовмещающих пород как основа для выявления механизмов их формирования // Геохимия, 2015, № 6, с. 1-14.

Baker L., Herlihy A.T., Kaufmann, P. R., Eilers, J. M. Acidic lakes and streams in United States: The role of asidic deposition. Science, 1991, v. 252 (5009), p. 1151-1154.

Blake R. The origin of high sodium bicarbonate waters in the Otway Basin, Victoria, Australia // Proceedings of 6th International Symposium on Water-Rock Interaction. Rotterdam, Brookfield, 1989, p. 83-85.

Doroshkevich S.G., Chernyavskii M.K., Ukraintsev A.V. The distribution of chemical elements in the landscapes of sulphate and soda lakes (West Transbaikalia) // Proceedings of 13th International Conference on Salt Lake Research (ICSLR 2017). Book of abstracts. Editors by E.Yu. Abidueva, D.D. Barhutova, V.V. Khakhinov. Ulan-Ude, Buryat State University Publishing Departament, 2017, p. 45-46.

Kimura K. Mechanism of the forming of ground water wits high content of sodium bicarbonate onto the plains part of the formation Kobe (Japan) // J. Ground Water Hydrology, 1992, v. 32 (1), p. 5-16.

Last W.M., Fawn M.G. Saline systems of the Great Rlains of Western Canada. An overview of the limnology and paleolimnology // Saline systems, 2005, p. 1-10.

Parkhurst D.L., Christenson S., Breit G.N. Groundwater quality assessment of the Central Oklahoma aquifer, Oklahoma. Geochemical and geohydrologic investigation // U.S. Geological Survey water-supply paper, 1996, N 2357, p. 101-110.

Plyusnin A.M., Peryazeva E.G. Water geochemical peculiarities of sulphate and soda salting hearths in west Transbaikalia. Regularities of the structure and evolution of geosphere // Proceedings of VII International Interdisciplinary Scientific Symposium and International Geoscience Programme (IGCP-476). Vladivostok, 2005, p. 333- 337.

Sofer, Z., Gat J.R. Activities and concentration of oxygen-18 in concentrated aqueous salt solutions: analytical and geophysical implications // Earth and Planetary Science Letters, 1975, v. 26, p. 179-186.

Stojanovic A., Kogelniga D. Major and trace element geochemistry of superficial sediments and suspended particulate matter of shallow saline lakes in Eastern Austria // Chemia der Erde, 2009, N 69, p. 223-234.

Volkova N.I. Geochemistry of rare elements in waters and sediments of alkaline lakes in the Sasykkul depression, East Pamirs // Chemical Geology, 1998, N 147, p. 265-277. 

Подрисуночные подписи к статье Плюснина А.М. и др. «Сульфатные минеральные озера...»

Рис. 1. Схема размещения минеральных озер на территории Западного Забайкалья. Условные обозначения: I - район расположения группы Алгинских озер; II -сульфатных минеральных озер в Гусиноозерско-Оронгойской впадине; 1- места отбора проб воды, 2очаги содового засоления поверхностных вод, 3- очаги сульфатного засоления (список опробованных озер приведен в подрисуночной подписи к рис. 2).

Рис. 2. Диаграмма анионного состава минеральных озер Западного Забайкалья. Условные обозначения: I - область расположения содовых минеральных озер ; II сульфатных минеральных озер; 1-оз. Малое Окуневое, 2-оз. Большое Окуневое, 3-0з. Долгое, 4-0з. Щучье, 5- оз. Нюдуне Аршан, 6-оз. Турхул, 7- оз. Витлаус, 8- оз. Витлаус 2, 9-03. Укырское, 10-0з. Куорка, 11- оз. Малое Алгинское, 12-оз. Гуджирчан, 13-оз. Большое Алгинское, 14- оз. Бормашевое, 15- оз. Степное, 16- оз. Белое, 17- оз. Тормь, 18- 03. Сульфатное, 19 - оз. Олонь Шибирь, 20- оз. Нижнее Белое, 21- оз. Верхнее Белое, 22- $о 3$. Каменный Ключ, 23- оз. Цайдам, 24-оз. Никитино, 25-оз. Долгое, 26- оз. Киранское, 27- оз. Амбон, 28- оз.Черное, 29- оз. Рыбное, 30- оз. Жамбалушкина.

Рис. 3. Космоснимок района разгрузки Алгинского термального источника и расположения минеральных озер. Условные обозначения: I - ландшафты низинных болот; II - степные ландшафты с крутыми склонами ; III - минеральные озера ; IV -отложения солей на поверхности почвогрунтов; 1- место разгрузки Алгинского термального источника, 2- оз. М. Алгинское, 3- 0з. Б.Алгинское, 4 - оз. Гуджирчан.

Рис. 4. Космоснимок района расположения оз Сульфатное. Условные обозначения: I - степные ландшафты впадины, II - лесостепные ландшафты с кустарниковой растительностью , III - пресные и соленые озера, IV - разрывные нарушения, выявленные при дешифрировании космоснимков.

Рис. 5. Космоснимок участка расположения минеральных озер Белое и Степное. Условные обозначения: I - степные ландшафты микровпадины, II - лесостепные ландшафты кристаллического обрамления, III - разрывные нарушения, выявленные при дешифрировании космоснимков , IV - минеральные озера , V - русла рек. 
Табл. 1. Макрокомпонентный состав Алгинского термального источника и озер с сульфатным натриевым типом воды, расположенных в Баргузинской впадине, мг/л.

\begin{tabular}{|c|c|c|c|c|c|c|c|c|c|}
\hline Водопункт & $\mathrm{pH}$ & TDS & $\mathrm{Na}$ & $\mathrm{Ca}$ & $\mathrm{Mg}$ & $\mathrm{HCO}_{3}$ & $\mathrm{SO}_{4}$ & $\mathrm{Cl}$ & $\mathrm{F}$ \\
\hline Алгинский источник, 2003 & 8,0 & 658,6 & 159,2 & 36,1 & 8,5 & 64,1 & 336,3 & 20,6 & 15,1 \\
\hline Алгинский источник, 2012 & 7,9 & 693,4 & 156,4 & 45,1 & 1,2 & 91,5 & 322,7 & 18,1 & 5,0 \\
\hline Алгинский источник, 2016 & 7,37 & 597 & 104,2 & 74,3 & 0,8 & 53,5 & 338 & 15,5 & 3,15 \\
\hline среднее & 7,76 & 650 & 139,9 & 51,8 & 3,5 & 69,7 & 332 & 18 & 7,75 \\
\hline Оз. М. Алгинское, 2003 & 8,97 & 15675 & 4950,3 & 7,5 & 86,5 & 1421,3 & 7764,5 & 1130,8 & 19,2 \\
\hline $\begin{array}{l}\text { Концентрирование } \\
\text { компонентов в растворе (в n }\end{array}$ & & & & & & & & & \\
\hline $\begin{array}{l}\text { раз) } \\
\text { Оз. Б. Алгинское, } 2003\end{array}$ & 7,96 & $\begin{array}{l}24,1 \\
1518,6\end{array}$ & $\begin{array}{l}35,4 \\
388,6\end{array}$ & $\begin{array}{l}0,14 \\
66,6\end{array}$ & $\begin{array}{l}24,7 \\
13,4\end{array}$ & $\begin{array}{l}20,4 \\
250,1\end{array}$ & $\begin{array}{l}23,4 \\
743,1\end{array}$ & $\begin{array}{l}62,8 \\
43,9\end{array}$ & $\begin{array}{l}2,5 \\
10,5\end{array}$ \\
\hline $\begin{array}{l}\text { Оз. Б. Алгинское, } 2016 \\
\text { Концентрирование }\end{array}$ & 7,5 & 9411,8 & 2415,7 & 363,8 & 84,2 & 154,9 & 5860 & 372,5 & 19,0 \\
\hline $\begin{array}{l}\text { компонентов в растворе (в } n \\
\text { раз) }\end{array}$ & & $\begin{array}{l}2,3- \\
14,5\end{array}$ & $\begin{array}{l}2,8- \\
17,3\end{array}$ & $\begin{array}{l}1,28- \\
7,02\end{array}$ & $\begin{array}{l}3,82- \\
24,06\end{array}$ & $\begin{array}{l}3,5- \\
2,2\end{array}$ & $\begin{array}{l}2,24- \\
17,6\end{array}$ & $\begin{array}{l}2,4- \\
24,0\end{array}$ & $\begin{array}{l}1,35- \\
2,4\end{array}$ \\
\hline Оз. Гуджирчан,2003 & 8,84 & 43268 & 14311,9 & 72,1 & 97,2 & 2775,2 & 23817,5 & 1956,8 & 14,21 \\
\hline $\begin{array}{l}\text { Оз. Гуджирчан,2010 } \\
\text { Концентрирование } \\
\text { компонентов в растворе (в n }\end{array}$ & 9,06 & 81324 & 26175,6 & 30,1 & 224,8 & 3600,0 & 47663,3 & 2778,6 & 17,48 \\
\hline раз) & & $\begin{array}{l}66,5- \\
125,1\end{array}$ & $\begin{array}{l}102,3- \\
187,1\end{array}$ & $\begin{array}{l}1,4- \\
0,6\end{array}$ & $\begin{array}{l}27,7- \\
64,2\end{array}$ & $\begin{array}{l}39,8- \\
51,6\end{array}$ & $\begin{array}{l}71,7- \\
143,5\end{array}$ & $\begin{array}{l}95- \\
154,4\end{array}$ & $\begin{array}{l}1,8- \\
2,2\end{array}$ \\
\hline
\end{tabular}


Табл. 2. Микроэлементный состав Алгинского источника и сульфатных минеральных озер Баргузинской впадины, мкг/л.

\begin{tabular}{|c|c|c|c|c|c|c|c|}
\hline $\begin{array}{l}\text { Хим. } \\
\text { элемент }\end{array}$ & $\begin{array}{l}\text { ист. } \\
\text { Алгинский }\end{array}$ & $\begin{array}{l}\text { оз. Б. } \\
\text { Алгинское }\end{array}$ & $\mathrm{K}_{1}$ & $\begin{array}{l}\text { оз. М. } \\
\text { Алгинское }\end{array}$ & $\mathrm{K}_{2}$ & $\begin{array}{l}\text { оз. } \\
\text { Гуджирчан }\end{array}$ & $\mathrm{K}_{3}$ \\
\hline $\mathrm{Li}$ & 97,7 & 569,1 & 5,8 & 2670,3 & 27,3 & 2595,8 & 26,6 \\
\hline B & 63,1 & 324,8 & 5,1 & 6845,8 & 108,5 & 12243,6 & 194,0 \\
\hline $\mathrm{Rb}$ & 26,66 & 74,84 & 2,8 & 70,74 & 2,6 & 60,86 & 2,3 \\
\hline Cs & 3,90 & 0,52 & 0,13 & 0,12 & 0,03 & 0,389 & 0,09 \\
\hline $\mathrm{Sr}$ & 1332,2 & 4136,9 & 3,1 & 2725,0 & 2,04 & 3150,6 & 2,4 \\
\hline $\mathrm{Ba}$ & 16,28 & 21,62 & 1,3 & 18 & 1,1 & 72,19 & 4,4 \\
\hline $\mathrm{Al}$ & 11,3 & 23,4 & 2,07 & 309,1 & 27,3 & 95,5 & 8,4 \\
\hline $\mathrm{P}$ & 36,2 & 71,6 & 1,97 & H.о. & H.O. & 4060,2 & 112,2 \\
\hline $\mathrm{Ti}$ & 0,68 & 1,55 & 2,3 & 24,4 & 35,9 & 10,22 & 15,0 \\
\hline $\mathrm{V}$ & 1,28 & 1,06 & 0,8 & 37,99 & 29,6 & 44,10 & 34,4 \\
\hline $\mathrm{Cr}$ & 1,61 & 3,57 & 2,2 & 2,64 & 1,6 & 2,54 & 1,6 \\
\hline Mn & 3,35 & 5,47 & 1,6 & 32,62 & 9,7 & H.O. & H.O. \\
\hline $\mathrm{Fe}$ & 81,03 & 307,8 & 3,8 & 438,29 & 5,4 & 194,21 & 2,4 \\
\hline Co & 0,018 & 0,04 & 2,2 & 1,75 & 97,2 & 0,22 & 12,2 \\
\hline $\mathrm{Ni}$ & 0,81 & 1,06 & 1,3 & 6,7 & 8,3 & 33,18 & 40,9 \\
\hline $\mathrm{Cu}$ & 1,71 & 3,46 & 2,0 & 66,21 & 38,7 & 44,93 & 26,3 \\
\hline $\mathrm{Zn}$ & 9,54 & 15,98 & 1,7 & 27,89 & 2,9 & 16,64 & 1,8 \\
\hline $\mathrm{Cd}$ & 0,02 & 0,11 & 5,35 & 0,63 & 31,5 & 0,70 & 35,1 \\
\hline $\mathrm{Pb}$ & 0,94 & 1,36 & 1,4 & 0,6 & 0,6 & 26,54 & 28,0 \\
\hline $\mathrm{Bi}$ & 0,018 & 0,134 & 7,4 & H.о. & H.о. & 0,269 & 14,9 \\
\hline As & 0,39 & 1,76 & 4,5 & 45,2 & 115,9 & 64,41 & 165,1 \\
\hline Mo & 12,07 & 16,48 & 1,4 & 249,8 & 20,7 & 188,2 & 15,6 \\
\hline Sn & 0,158 & 0,278 & 1,7 & 0,20 & 1,3 & H.O. & H.O \\
\hline $\mathrm{Sb}$ & 0,11 & 0,12 & 1,06 & 2,89 & 25,3 & 5,69 & 49,9 \\
\hline W & 20,36 & 95,74 & 4,7 & 424 & 20,8 & 1161,9 & 57,0 \\
\hline Th & 0,014 & 0,035 & 2,5 & 0,11 & 7,8 & 0,92 & 65,4 \\
\hline $\mathrm{U}$ & 4,29 & 1,12 & 0,3 & 17,0 & 3,9 & 34,58 & 8,1 \\
\hline
\end{tabular}

Примечание: н.о. - не определено. 
Табл. 3. Содержания редкоземельных элементов в термальном источнике Алгинский и сульфатных минеральных озерах Баргузинской впадины, мкг/л.

\begin{tabular}{|c|c|c|c|c|}
\hline Элемент & ист. Алгинский & оз. Б. Алгинское & оз. М. Алгинское & оз. Гуджирчан \\
\hline $\mathrm{La}$ & 0,1938 & 1,08 & 0,74 & H.O. \\
\hline $\mathrm{Ce}$ & 0,0466 & 0,62 & 0,37 & H.O. \\
\hline $\operatorname{Pr}$ & 0,3387 & 0,068 & 0,033 & 0,1251 \\
\hline $\mathrm{Nd}$ & 0,0205 & 0,25 & 0,42 & 0,2346 \\
\hline Sm & 0,0012 & 0,038 & 0,104 & 0,3305 \\
\hline $\mathrm{Eu}$ & 0,0008 & 0,0104 & 0,0129 & 0,0385 \\
\hline Gd & 0,0541 & 0,0342 & 0,0273 & 0,4076 \\
\hline $\mathrm{Tb}$ & 0,0004 & 0,0054 & 0,0097 & H.O. \\
\hline Dy & 0,0095 & 0,0214 & 0,0186 & H.O. \\
\hline Ho & 0,0006 & 0,0067 & 0,0002 & H.o. \\
\hline Er & 0,0061 & 0,0131 & 0,0481 & H.O. \\
\hline $\operatorname{Tm}$ & 0,0003 & 0,0019 & 0,0067 & 0,0463 \\
\hline $\mathrm{Yb}$ & 0,0223 & 0,0104 & 0,0295 & H.O. \\
\hline $\mathrm{Lu}$ & 0,001 & 0,0019 & 0,0045 & H.O. \\
\hline ¿ЛРЗЭ & 0,60 & 2,07 & 1,68 & \\
\hline$\sum$ ТР3Э & 0,06 & 0,10 & 0,14 & \\
\hline$\sum$ P3Э & 0,69 & 2,16 & 1,82 & \\
\hline$\left(\mathrm{Ce} / \mathrm{Ce}^{*}\right)_{\mathrm{N}}$ & 0,03 & 0,43 & 0,40 & \\
\hline$\left(\mathrm{Eu} / \mathrm{Eu}^{*}\right)_{\mathrm{N}}$ & 0,12 & 1,34 & 0,96 & \\
\hline$(\mathrm{La} / \mathrm{Yb})_{\mathrm{N}}$ & 0,64 & 7,65 & 1,85 & \\
\hline
\end{tabular}

Примечание: н.о. - не определено; Нормализация проводилась по PAAS, $\left(\mathrm{Ce} / \mathrm{Ce}{ }^{*}\right)_{\mathrm{N}}=2 \mathrm{Ce}_{\mathrm{N}} /$ $(\mathrm{La}+\mathrm{Pr})_{\mathrm{N}},\left(\mathrm{Eu} / \mathrm{Eu}^{*}\right)_{\mathrm{N}}=2 \mathrm{Eu}_{\mathrm{N}} /(\mathrm{Sm}+\mathrm{Gd})_{\mathrm{N}}, \sum \mathrm{P} 3 Э-$ сумма редкоземельных элементов. 
Табл. 4. Химический состав подземных вод, заключенных в селенгинской свите, мг/л (Борисенко и др., 1994).

\begin{tabular}{|l|l|l|l|l|l|l|l|l|l|l|}
\hline $\begin{array}{l}\text { Дата } \\
\text { опробования }\end{array}$ & $\mathrm{Ca}$ & $\mathrm{Mg}$ & $\mathrm{Na}+\mathrm{K}$ & $\mathrm{HCO}_{3}$ & $\mathrm{CO}_{3}$ & $\mathrm{SO}_{4}$ & $\mathrm{Cl}$ & $\mathrm{F}$ & $\begin{array}{l}\text { Общая } \\
\text { минерали } \\
\text {-зация }\end{array}$ & $\mathrm{rSO}_{4} / \mathrm{rCl}$ \\
\hline 06.08 .91 & 36 & 41 & 388 & 610 & 0,1 & 438 & 85 & 2,6 & 1609 & 3,81 \\
10.12 .91 & 44 & 41 & 384 & 635 & 18 & 425 & 82 & 0,05 & 1638 & 3,83 \\
08.04 .92 & 48 & 39 & 384 & 676 & 12 & 418 & 82 & 0,05 & 1665 & 3,77 \\
13.08 .92 & 22 & 45 & 570 & 1031 & 42 & 427 & 85 & 0,05 & 2227 & 3,72 \\
\hline
\end{tabular}


Табл. 5. Макрокомпонентный состав подземных вод в пределах водосборной площади оз. Сульфатное, мг/л.

\begin{tabular}{|l|l|l|l|l|}
\hline Параметры & Родник & \multicolumn{3}{|c|}{ Скважины } \\
\cline { 3 - 5 } & Булаг & 1 & 2 & 3 \\
\hline $\mathrm{pH}$ & 6,75 & 7,12 & 7,28 & 7,46 \\
$\mathrm{HCO}_{3}{ }^{-}$ & 372,2 & 192,2 & 253,2 & 283,7 \\
$\mathrm{SO}_{4}^{2-}$ & 30,24 & 16,8 & 242,5 & 201,5 \\
$\mathrm{Cl}^{-}$ & 8,16 & 5,32 & 8,16 & 51,41 \\
$\mathrm{Na}^{+}+\mathrm{K}^{+}$ & 120,54 & 53,9 & 177,64 & 197,03 \\
$\mathrm{Ca}^{2+}$ & 17,03 & 21,0 & 17,03 & 27,05 \\
$\mathrm{Mg}^{2+}$ & 12,16 & 3,65 & 12,16 & 12,77 \\
$\mathrm{~F}^{-}$ & 1,16 & 0,54 & 2,0 & 1,96 \\
$\mathrm{SiO}_{2}$ & 20,55 & 28,13 & 23,43 & 30,85 \\
$\mathrm{NO}_{3}{ }^{-}$ & 4,37 & 0,9 & 2,43 & 34,2 \\
$\mathrm{TDS}^{\mathrm{rSO}}$ & 560 & 293 & 711 & 773 \\
\hline
\end{tabular}


Табл. 6. Химический состав подземных вод юрских отложений Нижне-Оронгойской впадины, мг/л [Плюснин, Гунин, 2001].

\begin{tabular}{|l|l|l|l|l|l|l|l|l|l|l|l|l|}
\hline $\begin{array}{l}\text { Интервал } \\
\text { опробования, } \\
\text { м }\end{array}$ & $\begin{array}{l}\text { Дебит, } \\
\text { Л/с }\end{array}$ & $\mathrm{NH}_{4}$ & $\mathrm{Na}$ & $\mathrm{K}$ & $\mathrm{Ca}$ & $\mathrm{Mg}$ & $\mathrm{SO}_{4}$ & $\mathrm{Cl}$ & $\mathrm{HCO}_{3}$ & $\mathrm{CO}_{3}$ & $\mathrm{M}$ & $\begin{array}{l}\mathrm{rSO}_{4} \\
/ \mathrm{rCl}\end{array}$ \\
\hline $82-143$ & 2 & 0,6 & 259 & 2,2 & 22 & 36 & 289 & 78 & 347 & 48 & 918 & 2,74 \\
$146-250$ & 0,23 & 5,6 & 1080 & 4,5 & 162 & 115 & 2315 & 453 & 213 & 18 & 4270 & 3,78 \\
$340-490$ & 6,9 & 6,0 & 1184 & 4,9 & 252 & 200 & 3106 & 436 & 219 & 18 & 5329 & 5,27 \\
\hline
\end{tabular}


Табл. 7. Макрокомпонентный состав воды в сульфатных озерах Гусиноозерско-Оронгойской впадины, мг/л.

\begin{tabular}{|l|l|l|l|}
\hline Параметр & Сульфатное & Белое & Степное \\
\hline $\mathrm{pH}$ & 8,79 & 8,67 & 8,73 \\
$\mathrm{HCO}_{3}$ & 1159,4 & 778,0 & 1525,5 \\
$\mathrm{SO}_{4}$ & 3797,0 & 1413,0 & 18306,9 \\
$\mathrm{Cl}$ & 1579,8 & 302,3 & 2128,6 \\
$\mathrm{~F}$ & 2,58 & 3,5 & 9,9 \\
$\mathrm{Na}$ & 2719,2 & 733,8 & 6389,3 \\
$\mathrm{Ca}$ & 40,0 & 40,1 & 100,2 \\
$\mathrm{Mg}$ & 285,5 & 206,5 & 2247,7 \\
$\mathrm{Oбщ.мин}$ & 9654,8 & 3504,4 & 30808,8 \\
$\mathrm{rSO}_{4} / \mathrm{rCl}$ & 1,78 & 3,45 & 6,36 \\
\hline
\end{tabular}


Табл. 8. Содержание микроэлементов в исследованных сульфатных озерах ГусиноозерскоОронгойской впадины, мкг/л.

\begin{tabular}{|c|c|c|c|}
\hline Микроэлементы & Сульфатное & Белое & Степное \\
\hline $\mathrm{Li}$ & 1499 & 649,6 & 465 \\
\hline $\mathrm{Be}$ & 0,09 & 1,06 & 0,002 \\
\hline B & 641,33 & 506,8 & 230 \\
\hline $\mathrm{Al}$ & 5,5 & 6,3 & 90 \\
\hline$P$ & 412,14 & 2,98 & 185 \\
\hline Sc & 0,0046 & 0,036 & 0,033 \\
\hline $\mathrm{Ti}$ & 5,64 & 2,82 & 36 \\
\hline $\mathrm{V}$ & 4,15 & 5,62 & 27,5 \\
\hline $\mathrm{Cr}$ & 0,9 & 4,49 & 1,45 \\
\hline $\mathrm{Mn}$ & 0,18 & 0,22 & 22,05 \\
\hline $\mathrm{Fe}$ & 93,12 & 88,8 & 61,5 \\
\hline Co & 0,89 & 0,11 & 1,25 \\
\hline $\mathrm{Ni}$ & 0,24 & 0,2 & 4,55 \\
\hline $\mathrm{Cu}$ & 1,12 & 5,14 & 7,85 \\
\hline $\mathrm{Zn}$ & 1,68 & 1,52 & 4,5 \\
\hline $\mathrm{Ga}$ & 0,0061 & 0,0058 & 0,105 \\
\hline Ge & 0,086 & H.O. & 0,485 \\
\hline As & 37,3 & 7,04 & 31,5 \\
\hline Se & 2,37 & 0,08 & 0,65 \\
\hline $\mathrm{Br}$ & 18,3 & 6,8 & H.O. \\
\hline $\mathrm{Rb}$ & 7,39 & 3,23 & 8,2 \\
\hline $\mathrm{Sr}$ & 3656,2 & 5193 & 18890 \\
\hline $\mathrm{Y}$ & 0,09 & 0,11 & 0,215 \\
\hline $\mathrm{Zr}$ & 7,44 & 2,28 & 1,15 \\
\hline $\mathrm{Nb}$ & 0,047 & 0,015 & 0,0465 \\
\hline Mo & 11,02 & 6,39 & 80,0 \\
\hline $\mathrm{Cd}$ & 0,047 & 0,05 & 0,48 \\
\hline Sn & 0,33 & 1,217 & 0,26 \\
\hline $\mathrm{Sb}$ & 11,1 & 1,17 & 3,0 \\
\hline Cs & 0,038 & 0,086 & 0,265 \\
\hline $\mathrm{Ba}$ & 44,61 & 17,79 & 125,0 \\
\hline Hf & 0,15 & 0,1 & 0,037 \\
\hline W & 3,56 & 0,39 & 14,4 \\
\hline $\mathrm{Tl}$ & 0,0082 & 0,0214 & 0,13 \\
\hline $\mathrm{Pb}$ & 3,68 & 8,68 & 15,5 \\
\hline $\mathrm{Bi}$ & 0,018 & 0,022 & 0,32 \\
\hline Th & 0,115 & 0,166 & 0,065 \\
\hline $\mathrm{U}$ & 33,42 & 5,73 & 85 \\
\hline
\end{tabular}


Табл. 9. Содержания редкоземельных элементов в сульфатных и содовых минеральных озёрах Гусиноозерско-Оронгойской впадины, мкг/л.

\begin{tabular}{|l|r|r|r|}
\hline Элемент & Сульфатное & & Степное \\
\hline $\mathrm{La}$ & 0,402 & 0,397 & 0,195 \\
$\mathrm{Ce}$ & 0,108 & 0,336 & 0,250 \\
$\mathrm{Pr}$ & 0,142 & 0,209 & 0,0200 \\
$\mathrm{Nd}$ & 0,0021 & 0,151 & 0,150 \\
$\mathrm{Sm}$ & 0,0023 & 0,0023 & 0,0200 \\
$\mathrm{Eu}$ & 0,0018 & 0,0018 & 0,0265 \\
$\mathrm{Gd}$ & 0,0173 & 0,004 & 0,0135 \\
$\mathrm{~Tb}$ & 0,0014 & 0,0014 & 0,0095 \\
$\mathrm{Dy}$ & 0,0023 & 0,0039 & 0,0115 \\
$\mathrm{Ho}$ & 0,0084 & 0,0177 & 0,050 \\
$\mathrm{Er}$ & 0,0014 & 0,0014 & 0,2150 \\
$\mathrm{Tm}$ & 0,0039 & 0,0018 & 0,0025 \\
$\mathrm{Yb}$ & 0,006 & 0,037 & 0,0135 \\
$\mathrm{Lu}$ & 0,0009 & 0,0009 & 0,0020 \\
$\sum$ ЛP3Э & 0,66 & 1,10 & 0,66 \\
$\sum \mathrm{TP} 3 Э$ & 0,04 & 0,07 & 0,32 \\
$\sum \mathrm{P3Э}$ & 0,70 & 1,17 & 0,98 \\
$(\mathrm{Ce} / \mathrm{Ce})_{\mathrm{N}}$ & 0,1 & 0,25 & 0,85 \\
$(\mathrm{Eu} / \mathrm{Eu})_{\mathrm{N}}$ & 3,99 & 8,3 & 22,5 \\
$(\mathrm{La} / \mathrm{Yb})_{\mathrm{N}}$ & 4,94 & 0,79 & 1,06 \\
\hline
\end{tabular}


Табл. 10. Макрокомпонентный состав донных отложений озер Гусиноозерско-Оронгойской впадины,\% (в каждом озере проанализировано 8 проб).

\begin{tabular}{|l|l|l|l|l|}
\hline Показатель & Щучье & Гусиное & Белое & Сульфатное \\
\hline $\mathrm{SiO}_{2}$ & $\underline{51,3-64,2}$ & $\underline{48,6-68,1}$ & $19,3-24,7$ & $32,4-49,6$ \\
& $59,7(2,2)$ & $63,8(2,3)$ & $22,5(2,2)$ & $42,4(2,3)$ \\
$\mathrm{Al}_{2} \mathrm{O}_{3}$ & $\underline{11,4-15,8}$ & $\underline{6,8-16,2}$ & $4,4-7,8$ & $6,8-9,45$ \\
& $13,8(5,2)$ & $12,1(4,8)$ & $6,2(5,1)$ & $8,7(4,9)$ \\
$\mathrm{Fe}_{2} \mathrm{O}_{3}$ & $\underline{2,43-6,14}$ & $\underline{1,72-6,2}$ & $2,18-3,06$ & $1,27-1,89$ \\
& $5,17(16,1)$ & $4,16(15,9)$ & $2,34(15,8)$ & $1,56(16,2)$ \\
$\mathrm{MnO}$ & $\underline{0,09-0,11}$ & $\underline{0,07-0,12}$ & $0,09-0,13$ & $0,11-0,14$ \\
& $0,11(18)$ & $0,11(18)$ & $0,12(18)$ & $0,12(18)$ \\
$\mathrm{CaO}$ & $\underline{1,19-3,94}$ & $\underline{1,92-12,81}$ & $26,4-30,2$ & $13,6-23,2$ \\
& $1,72(20,4)$ & $6,87(19,8)$ & $28,4(19)$ & $18,3(21)$ \\
$\mathrm{MgO}$ & $\underline{0,98-3,14}$ & $\underline{0,62-1,81}$ & $3,9-5,32$ & $1,85-2,15$ \\
& $1,17(35)$ & $1,43(36)$ & $4,9(37)$ & $2,04(34)$ \\
$\mathrm{TiO}_{2}$ & $\underline{0,85-1,54}$ & $\underline{0,19-0,84}$ & $0,21-0,42$ & $0,29-0,82$ \\
& $1,28(15)$ & $0,58(16)$ & $0,28(17)$ & $0,63(15)$ \\
$\mathrm{K}_{2} \mathrm{O}$ & $\underline{1,97-3,12}$ & $\underline{2,09-3,84}$ & $0,93-1,36$ & $1,64-2,12$ \\
& $2,46(6,3)$ & $2,52(6,5)$ & $1,12(3,1)$ & $1,87(6,6)$ \\
$\mathrm{Na}_{2} \mathrm{O}$ & $\underline{2,12-3,16}$ & $\underline{1,32-3,2}$ & $1,08-1,72$ & $2,89-3,64$ \\
& $2,72(24,8)$ & $2,42(25,3)$ & $1,26(17,8)$ & $3,12(23,8)$ \\
$\mathrm{P}_{2} \mathrm{O}_{5}$ & $0,19-0,42$ & $0,13-0,29$ & $0,07-0,11$ & $0,08-0,12$ \\
ППП & $3,08-5,42$ & $6,8-20,1$ & $26,1-32,3$ & $1,02-1,94$ \\
\hline
\end{tabular}

Примечание: в числителе - пределы содержаний, в знаменателе - среднее, в скобках погрешность, \%. ППП - потери при прокаливании. 
Табл. 11. Средние содержания микроэлементов в донных отложениях озер (в выборке по каждому озеру обработано 8 проб, в скобках приведены пределы содержаний), г/т.

\begin{tabular}{|c|c|c|c|c|}
\hline \multirow[t]{2}{*}{ Элемент } & Гусиное & Щучье & Белое & Сульфатное \\
\hline & \multicolumn{2}{|c|}{ пресные } & \multicolumn{2}{|c|}{ сульфатные } \\
\hline Sc & $12(10.6-13.4)$ & $14(12.3-15.7)$ & $8.6(7.6-9.6)$ & $9.5(8.4-10.6)$ \\
\hline $\mathrm{V}$ & $95(83.6-106.4)$ & $104(91.5-116.5)$ & $39.0(34.3-43.7)$ & $47(41.4-52.6)$ \\
\hline $\mathrm{Cr}$ & $56(49.3-62.7)$ & $43(37.8-48.2)$ & $32.0(28.2-35.8)$ & $22(19.4-24.6)$ \\
\hline Co & $12(10.6-13.4)$ & $12(10.6-13.4)$ & $6.2(5.5-6.9)$ & $5.7(5.0-6.4)$ \\
\hline $\mathrm{Ni}$ & 7.2(6.3-8.1) & 20.8(18.3-23.3) & $6.2(5.5-6.9)$ & $14.3(12.6-16.0)$ \\
\hline $\mathrm{Cu}$ & $10(8.8-11.2)$ & $16(14.1-17.9)$ & 11(9.7-12.3) & 10.6(9.3-11.9) \\
\hline $\mathrm{Zn}$ & $34(30.0-38.0)$ & $52(45.8-58.2)$ & 21(18.5-23.5) & $27(23.8-30.2)$ \\
\hline $\mathrm{Ga}$ & $14(12.3-15.7)$ & 19.4(17.1-21.7) & $5(4.4-5.6)$ & $12.4(10.9-13.9)$ \\
\hline As & $5.2(4.6-5.8)$ & $4.6(4.1-5.1)$ & $6.2(5.5-6.9)$ & $5,2(4,6-5,8)$ \\
\hline $\mathrm{Rb}$ & 131(115.3-146.7) & $96(84.5-107.5)$ & 11(9.7-12.3) & $68(59,8-76,2)$ \\
\hline $\mathrm{Sr}$ & $399(351-447)$ & $247(217-276)$ & 21(18.5-23.5) & 979(861-1096) \\
\hline $\mathrm{Y}$ & $13(11.4-14.6)$ & $53(46.6-59.4)$ & $5(4.4-5.6)$ & 34(29.9-38.0-1) \\
\hline $\mathrm{Zr}$ & $165(145-185)$ & $15(13.2-16.8)$ & $6.2(5.5-6.9)$ & $667(586-747)$ \\
\hline $\mathrm{Nb}$ & $11(9.7-12.3)$ & $22(19.4-24.6)$ & 11(9.7-12.3) & $19(16.7-21.3)$ \\
\hline Mo & $1.5(1.3-1.7)$ & $2(1.8-2.2)$ & $21(18.5-23.5)$ & $1.7(1.5-1.9)$ \\
\hline $\mathrm{Ag}$ & $4.5(4.0-5.0)$ & $<0.6$ & $5(4.4-5.6)$ & $<0.6$ \\
\hline $\mathrm{Ba}$ & $932(820-14-043)$ & $669(588-750)$ & $270(237-302)$ & $500(440-560)$ \\
\hline $\mathrm{La}$ & 21(18.5-23.5) & $64(56.3-71.7)$ & $37(32.5-41.5)$ & $41(36.1-45.9)$ \\
\hline $\mathrm{Ce}$ & $55(48.4-61.6)$ & 105(92.4-117.6) & $48(42.2-53.8)$ & $79(69.5-88.5)$ \\
\hline Hf & $2.3(2.0-2.6)$ & $40(35.2-44.8)$ & $4.2(3.7-4.7)$ & $18(15.8-20.2)$ \\
\hline W & $2.4(2.1-2.7)$ & $\mathrm{H} / \mathrm{O}$ & 7.3(6.4-8.1) & $\mathrm{H} / \mathrm{O}$ \\
\hline $\mathrm{Pb}$ & $19(16.7-21.2-3)$ & 26(28.9-29.1) & $8(7.0-9.0)$ & 13.4(11.8-15.0) \\
\hline Th & $5.7(5.0-6.4)$ & 15.7(13.8-17.6) & $4.8(4.2-5.4)$ & 14(12.3-15.7) \\
\hline $\mathrm{U}$ & $3.5(3.1-3.9)$ & $7.8(6.9-8.7)$ & $2.4(2.1-2.7)$ & $8.2(7.2-9.2)$ \\
\hline $\mathrm{Br}$ & $<5$ & $<5$ & 7.3(6.4-8.2) & 38 (33.4-42.6) \\
\hline
\end{tabular}

Примечание: н/о - не определено. 
Табл. 12. Индекс насыщения озерных вод карбонатами и сульфатами.

\begin{tabular}{|l|l|l|l|l|l|l|l|l|l|}
\hline $\begin{array}{l}\text { Минералы/ } \\
\text { Название озер }\end{array}$ & кальцит & доломит & магнезит & стронцианит & гипс & эпсомит & кизерит & сакиит & мирабилит \\
\hline Сульфатное & 3,14 & 11,43 & 4,50 & 2,24 & $-1,81$ & $-5,50$ & $-59,45$ & $-96,69$ & $-131,33$ \\
Белое & 2,57 & 9,97 & 3,61 & 2,04 & $-1,73$ & $-5,74$ & $-59,70$ & $-96,93$ & $-131,281$ \\
Степное & 2,92 & 12,14 & 5,42 & 2,76 & $-1,22$ & $-3,79$ & $-57,72$ & $-94,97$ & $-129,539$ \\
Малое Алгинское & 1,64 & 8,92 & 3,48 & 2,13 & $-3,32$ & $-6,54$ & $-60,49$ & $-97,73$ & $-129,901$ \\
Большое Алгинское & 1,15 & 3,89 & $-1,05$ & 0,33 & $-1,23$ & $-8,48$ & $-62,45$ & $-99,67$ & $-135,64$ \\
Гуджирчан & $-7,42$ & 1,35 & 4,99 & 2,78 & $-11,9$ & $-7,12$ & $-60,81$ & 98,27 & $-125,90$ \\
\hline
\end{tabular}




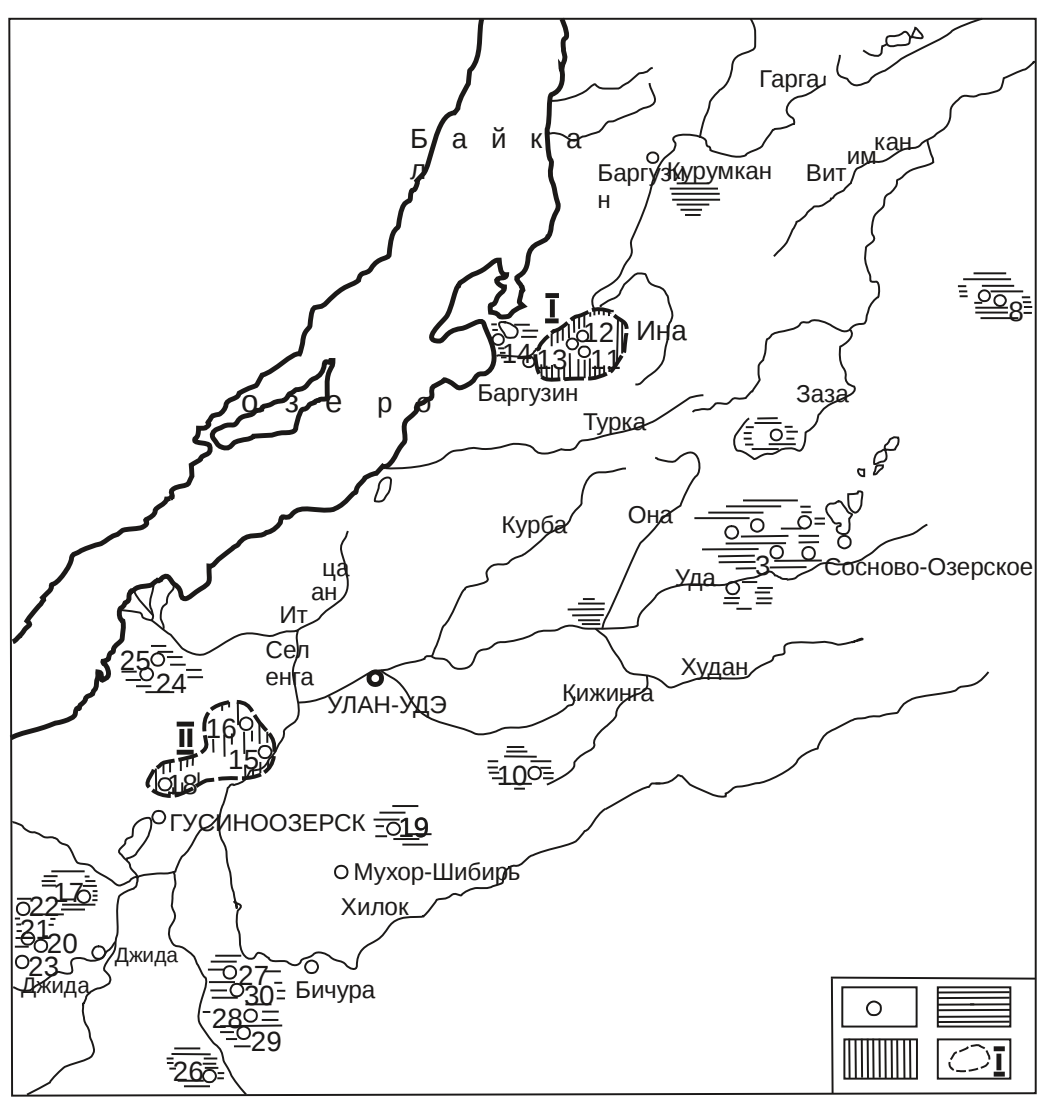




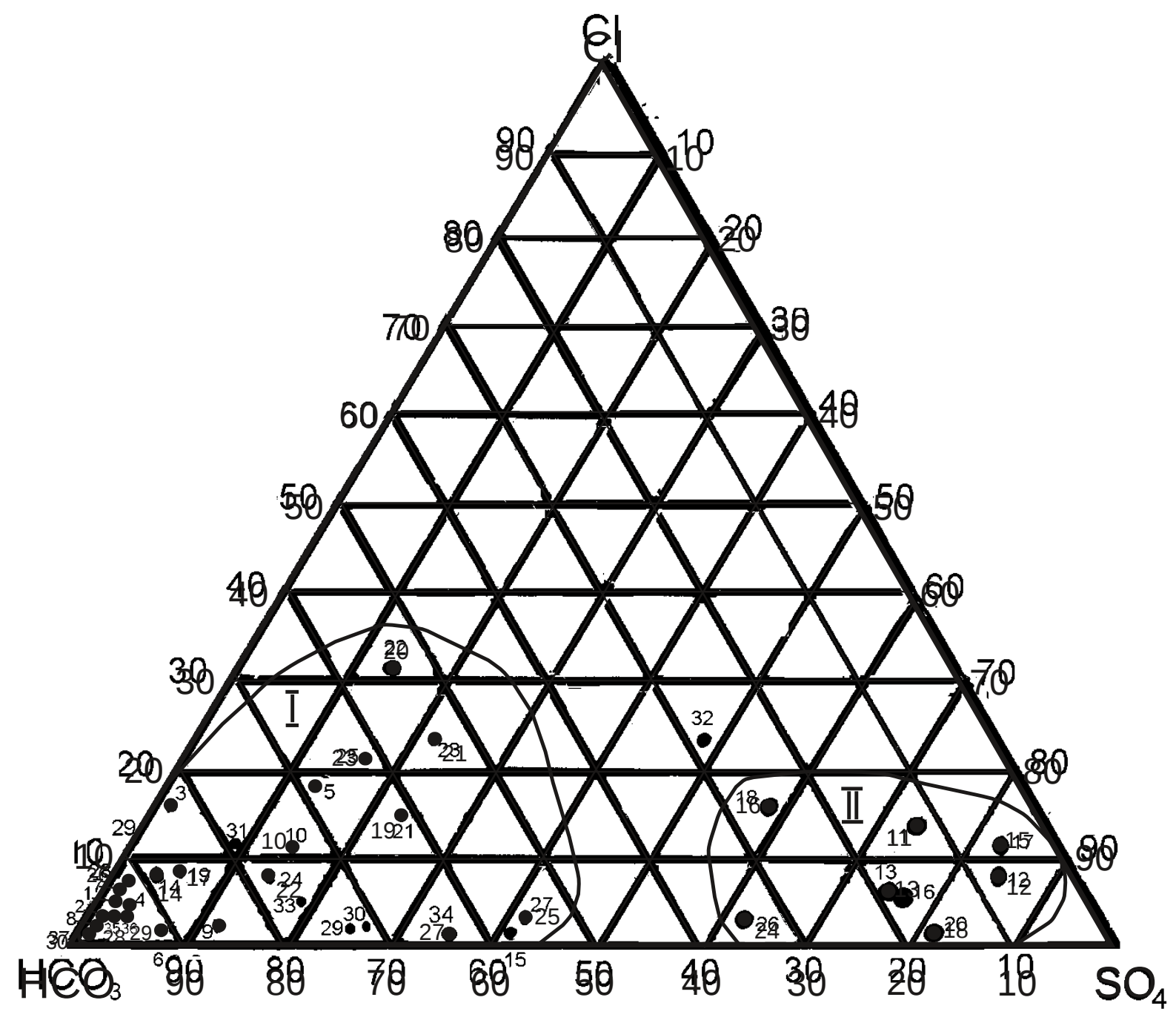




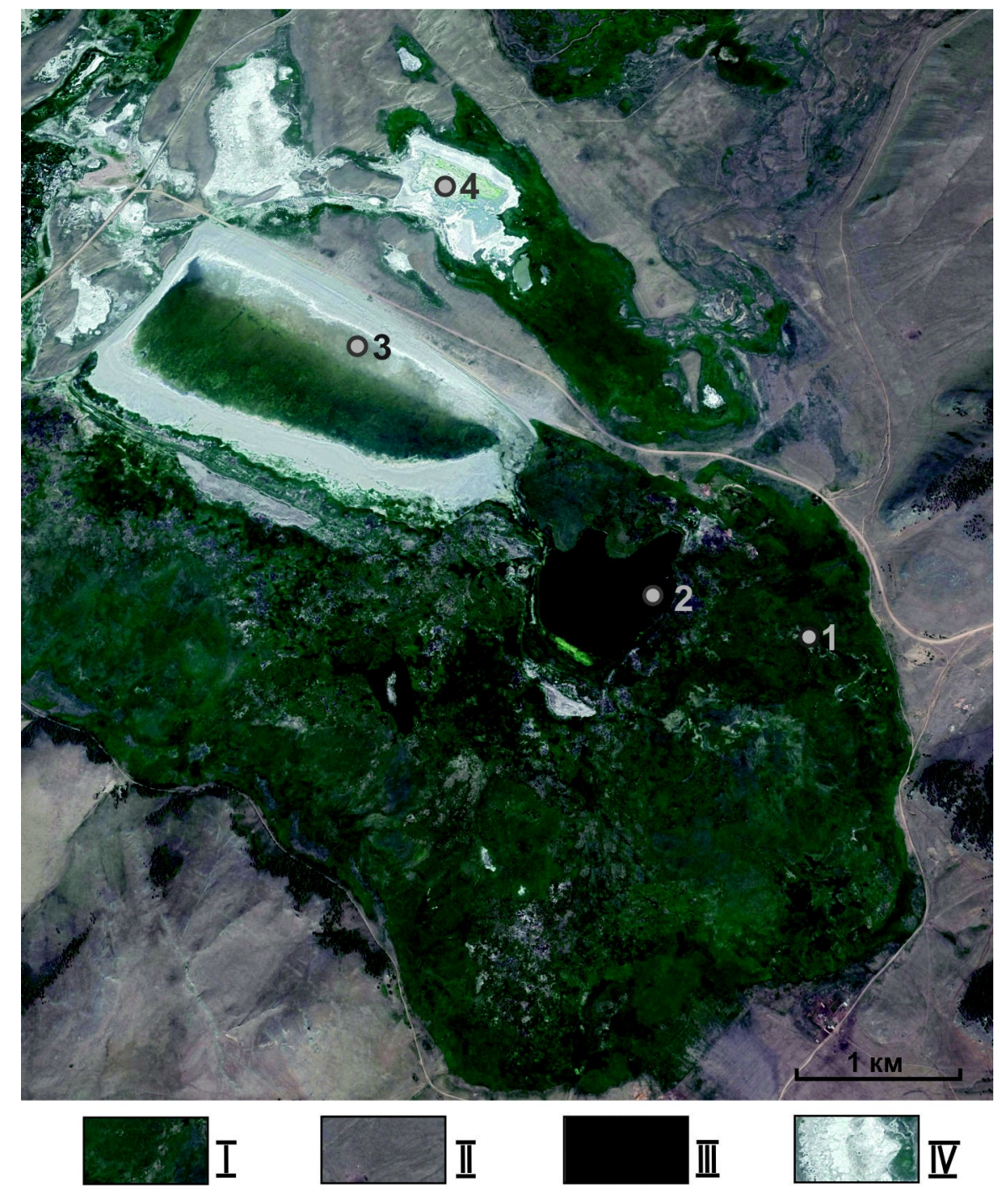




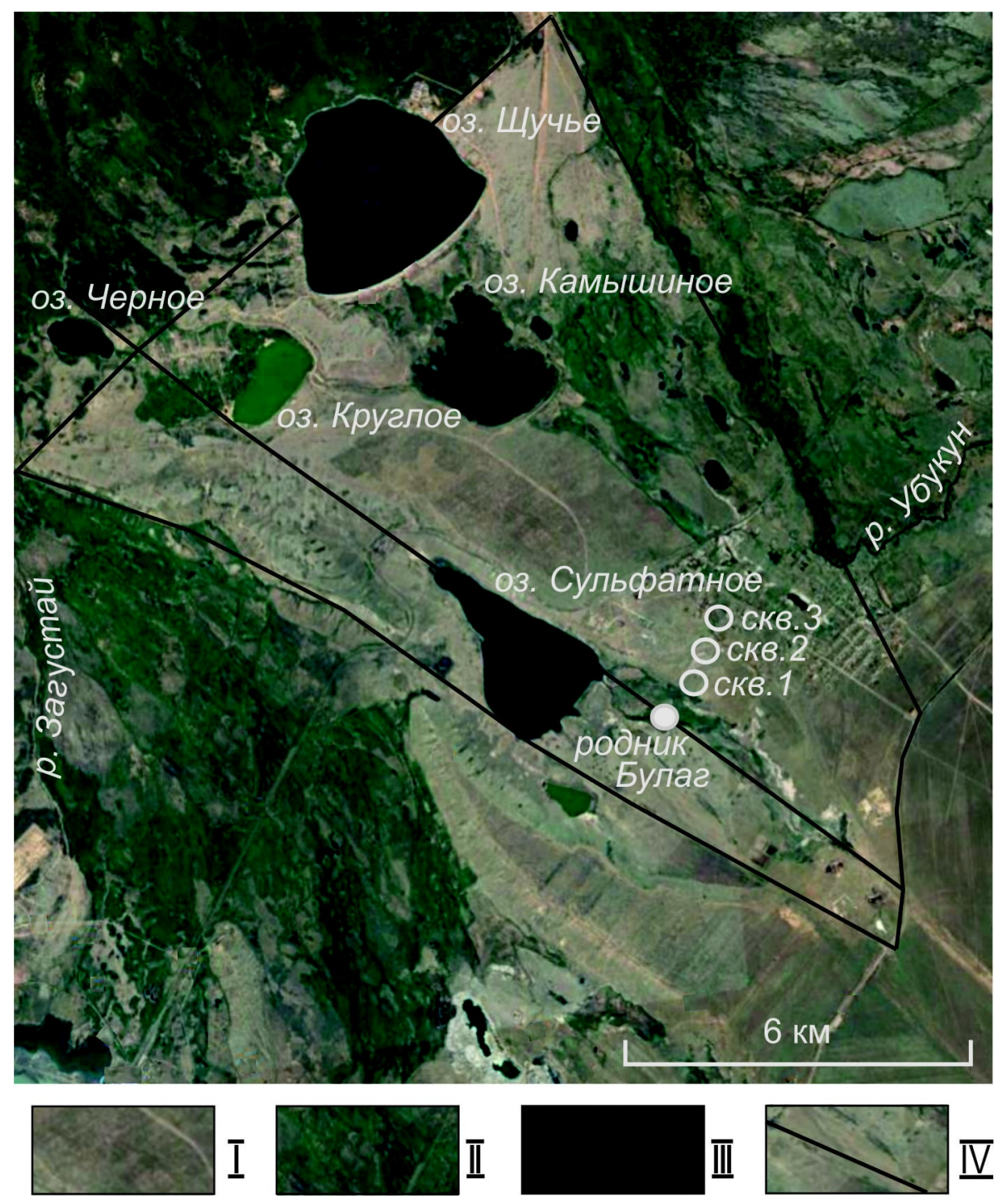




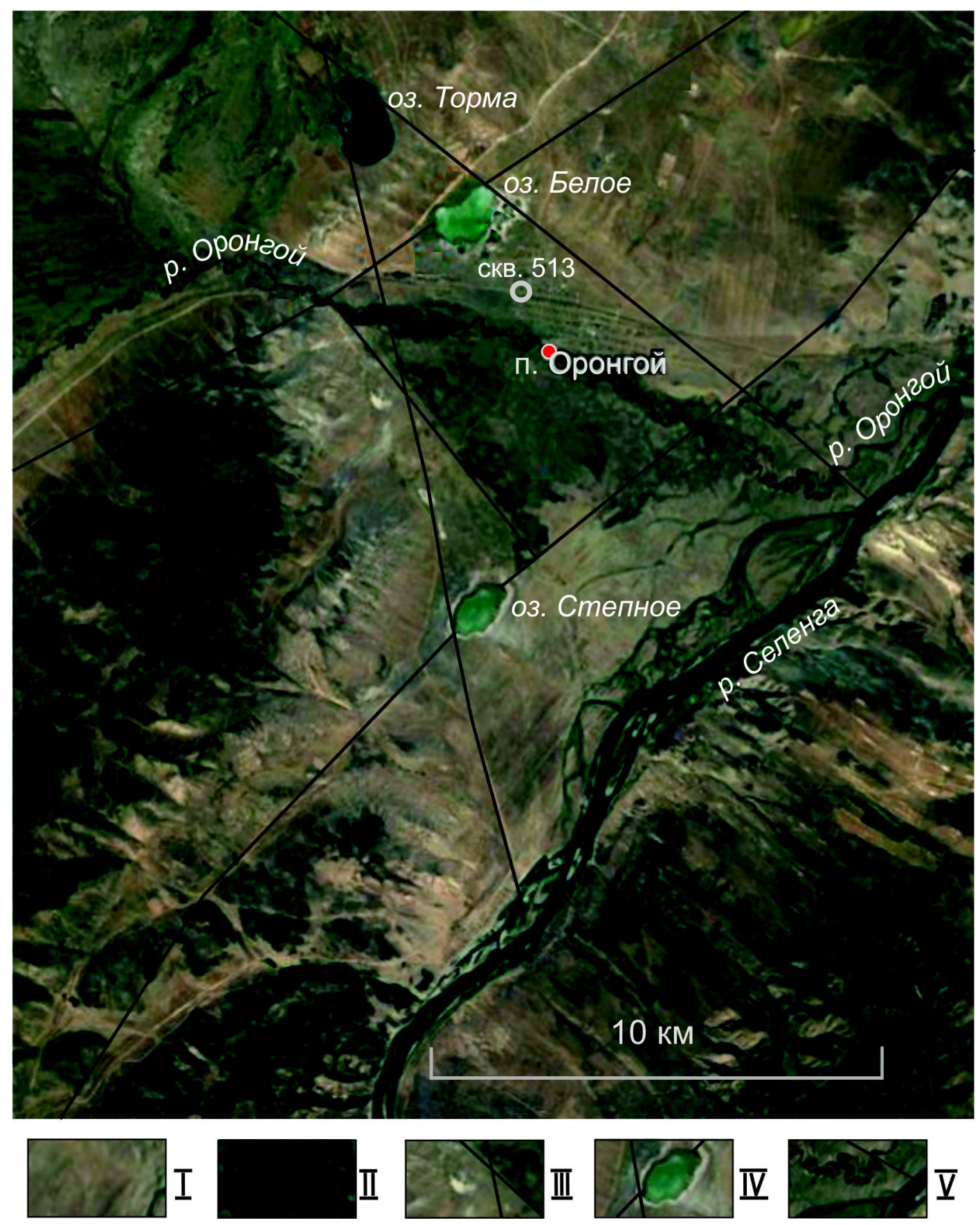

